\title{
CASOS RECIENTES QUE PLANTEAN EL DIFÍCIL EQUILIBRIO ENTRE LA BÚSQUEDA DE LA VERDAD BIOLÓGICA Y LA ESTABILIDAD DEL ESTADO CIVIL DE FILIACIÓN
}

\author{
Case Law Regarding the Difficult Balance between the Search of \\ Biological Truth and the Stability of the Legal Parentage
}

\section{SUSANA QUICIOS MOLINA \\ Profesora Titular de Derecho Civil \\ Universidad Autónoma de Madrid}

\author{
Recepción: 07/07/2015 \\ Aceptación después de revisión: 30/09/2015 \\ Publicación: 27/11/2015
}

I. EL CONFLICTO DE INTERESES SUBYACENTE EN TODA DEMANDA DE FILIACIÓN. II. El CASO DEL PADRE QUE QUIERE SERLO CUANDO EL HIJO ES MAYOR DE EDAD: 1. La solución dada por la STS de 3 de diciembre de 2014.2. Cómo podría haberse resuelto por el Tribunal Supremo: falta de interés legítimo del progenitor biológico y abuso de derecho. 3. Cómo podrá resolverse tras la reforma del artículo 133 CC. III. EL CASO DEL HIJO QUE QUIERE SERLO CUANDO EL PADRE O LA MADRE HA FALLECIDO: 1. La solución dada por la STS de 12 de enero de 2015. 2. Cómo podría haberse resuelto por el Tribunal Supremo: abuso del derecho del hijo biológico. 3. Decisiones del Tribunal Europeo de Derechos Humanos. IV. Revisión DE SENTENCIAS FIRMES SOBRE FILIACIÓN: 1. Las SSTS de 12 de diciembre de 2014 y 11 de octubre de 2007. 2. Hacia la absoluta transparencia de la realidad biológica. 3. Decisiones del Tribunal Europeo de Derechos Humanos.

\section{RESUMEN}

¿Está legitimado el progenitor para reclamar que se declare judicialmente su paternidad aunque se haya desentendido del hijo cuando era menor de edad? ¿Está legitimado el hijo para reclamar que se declare judicialmente su filiación cuando el progenitor ya ha fallecido? ¿Puede revisarse una sentencia firme si se presenta una prueba biológica realizada con posterioridad al proceso? El Tribunal Supremo ha entendido que el interés en hacer coincidir la filiación real con la legal prevalece sobre la estabilidad del estado civil y la seguridad jurídica.

PALABRAS CLAVE: Acciones de filiación; búsqueda de la verdad biológica; seguridad jurídica. 


\begin{abstract}
Is the parent entitled to claim paternity of a child even if he has ignored him/ her when he/she was a minor? Is the child entitled to bring a legal action to determine parentage when the parent has already died? Could a final judgment be reversed if there is a biological test carried out after the end of the legal proceedings? The Supreme Court has held that interest in estabishing biological parentage prevails over the stability of civil status and legal certainty.
\end{abstract}

KEY WORDS: Parentage actions; search for biological truth; legal certainty.

\title{
I. EL CONFLICTO DE INTERESES SUBYACENTE EN TODA DEMANDA DE FILIACIÓN
}

Siempre que se interpone una acción de filiación, ya sea para que quede determinada legalmente la paternidad o maternidad reclamada o para que deje de estar determinada legalmente la filiación de una persona si se impugna (la filiación o el título en virtud del cual se determinó extrajudicialmente), el juez ha de optar por alterar el status quo privado y familiar existente o mantener dicho status. La decisión implica elegir qué interés legítimo, de los varios afectados, resulta prevalente en el caso. Si el interés preferente se considera que es la concordancia de la filiación legal con la biológica (que conste como padre o madre legal solo el que biológicamente lo es), se alterará el estado civil de filiación, ya sea porque triunfe la demanda de reclamación interpuesta o porque triunfe la demanda de impugnación. En cambio, si el interés prevalente se considera que es la estabilidad de la relación de estado existente (así como la seguridad jurídica), deberá desestimarse la demanda sobre filiación. Evidentemente las soluciones elegidas por el legislador para los conflictos regulados están inspiradas en uno u otro principio esencial (la concordancia de la filiación legal con la biológica o la estabilidad del estado civil de filiación), y estas soluciones vinculan a los tribunales, pero ni todos los posibles conflictos están previstos por el legislador ni las soluciones legales deben ser las que aparentemente se derivan de la letra de un artículo.

El intérprete y aplicador del Derecho de filiación tiene una complicada labor debido a los cambios sociales que en esta materia llevan años produciéndose, cambios derivados tanto de las enormes posibilidades que la ciencia médica ofrece (fácil comprobación de la filiación biológica de una persona, técnicas de reproducción asistida) como de los valores imperantes. Estos cambios sociales han llevado a los ciudada- 
nos a plantear ante los tribunales demandas nuevas de muy difícil solución, que requieren para su resolución un conocimiento profundo del Derecho de filiación, de sus principios y reglas fundamentales ${ }^{1}$. También en el debate sobre la mejor solución que cabe dar a estos casos aparecen conceptos generales como retraso desleal, abuso del derecho, fraude de ley, actos propios, cuya aplicación es siempre delicada. A pesar de la complejidad de los supuestos prácticos, y del desconcierto causado por la rápida evolución de las opiniones sobre la familia (fundamento, origen, composición, derechos, deberes, etc.), calmadamente han de utilizarse conceptos jurídicos básicos que, bien entendidos y aplicados, permiten llegar a soluciones sensatas. Por poner solo un ejemplo especialmente significativo, ahí tenemos el caso del intercambio de embriones que por error se produjo en un hospital italiano (los de una pareja se implantaron en la otra, y viceversa), resultando que los gemelos nacidos, cuya filiación se atribuyó a la madre gestante y a su marido (que conocedores del error consintieron continuar con el embarazo), portaban los genes de la otra pareja, mientras que los embriones implantados a la mujer de esta pareja no fueron viables. El tribunal de Roma que resolvió en agosto de 2014 la demanda de la madre y el padre genéticos para que constasen su maternidad y paternidad rechazó esta petición, y como se ha señalado por la doctrina la solución a esta situación tan dramática se ha extraído de los principios generales que informan el sistema de filiación en general, pues la ley italiana no prevé una acción como la entablada ${ }^{2}$. La maternidad se determina por el parto, y el vínculo que crea el embrión con la madre gestante, y por supuesto después, justifican que el interés de los menores nacidos radique en que quede determinada esta maternidad; en cuanto a la paternidad, se presume legalmente que lo es el marido de la madre, que ha consentido la

${ }^{1}$ Los casos más recientes resueltos en España sobre filiación derivada de técnicas de reproducción asistida han sido estudiados en profundidad por FARNÓs AMORÓs, E., «La filiación derivada de reproducción asistida: voluntad y biología», en Anuario de Derecho Civil, enero-marzo 2015, pp. 5 y ss.

${ }^{2}$ Es muy recomendable la lectura de la nota a la ordinanza del Tribunal de Roma de 20 de agosto de 2014 de BIANCA, M., «Il diritto del minore ad avere due soli genitori: riflessioni a margine della decisione del Tribunale di Roma sull'erroneo scambio degli embrioni», en Il Diritto di famiglia e delle persone, vol. XLIV, enero-marzo 2015 , pp. 186 y ss. Se plantea la autora cómo debería regular el legislador esta situación excepcional de error en la implantación de embriones, de tan incierto desarrollo porque las decisiones de los protagonistas pueden ser diversas: por ejemplo, cabría admitir que la madre gestante renunciase a su maternidad una vez nacido el niño, y en ese caso sería defendible que los progenitores genéticos tuvieran preferencia para que se les atribuyese la filiación legal (ob. cit., p. 196). 
fecundación artificial y ha aceptado a los nacidos como hijos aun sabiendo que biológicamente no lo eran. El interés de los menores reside en mantener los lazos efectivos ya creados con su madre gestante (también biológica) y el marido de esta, que ha actuado como padre; es decir, el interés del menor se entiende coincidente en este caso con el principio de estabilidad del estado civil.

El intérprete y aplicador del Derecho de filiación tiene también una complicada labor porque las consecuencias de su decisión sobre una acción de reclamación o impugnación van mucho más allá del proceso de filiación, debido a los efectos de muy diversa índole asociados a este estado civil. Tras este proceso puede que se abra otro en el que deberá decidirse sobre alguno de los efectos derivados de la filiación, siendo la solución a este conflicto también muy compleja. La pretensión de devolución de los alimentos pagados por el padre matrimonial que ha impugnado con éxito su paternidad (tras divorciarse de la madre del hijo) es un claro ejemplo de la cuestión que planteo, y lo traigo a colación aquí porque recientemente el Tribunal Supremo ha fijado su doctrina, muy importante para homogeneizar las distintas doctrinas de las Audiencias Provinciales. El Pleno de la Sala Primera, en sentencia de 24 de abril de 2015, ha resuelto, no sin división (dos magistrados formulan un voto particular), que no procede estimar la demanda de cobro de lo indebido, con base en el artículo 1895 del Código Civil, ejercitada por quien ha venido pagando alimentos al hijo por ser legalmente su padre, sin serlo biológico, contra la madre del menor ${ }^{3}$. En el caso, habiendo nacido la hija en 1990, se habían reclamado solo los alimentos pagados desde que se fijó la correspondiente pensión en el convenio regulador hasta la sentencia en que se estima la demanda de impugnación de la paternidad (de diciembre de 2002 a octubre de 2007). La demanda de reclamación de cantidad había sido estimada por el Juzgado de Tarancón que resolvió en primera instancia, pero desestimada por la Audiencia Provincial de Cuenca. El Tribunal Supremo desestima el recurso de casación decantándose por la doctrina de las Audiencias contraria a la existencia de cobro de lo indebido porque se consideran debidos los alimentos mientras esté determinada legalmente la paternidad (aunque no coincida con la verdad biológica); en definitiva, considera el Tribunal Supremo que aunque la realidad biológica es la base principal de las relaciones de paternidad, han de valorarse otras consideraciones

${ }^{3}$ STS n. $^{\circ}$ 202/2015, de 24 de abril (RJA 2015, 1915). Ponente: Excmo. Sr. D. José Antonio Seijas Quintana. El voto particular lo firman los magistrados Salas Carceller y Orduña Moreno. 
al resolver sobre los efectos derivados del éxito de demandas de impugnación de paternidad. En el voto particular se parte de una premisa distinta: al fundarse la deuda de alimentos en la paternidad biológica, son indebidos los pagados por quien constando como verdadero progenitor ha resultado no ser el padre biológico, y no hay razón para no aplicar en el caso esta consecuencia del fundamento de la filiación por naturaleza. Considerada la verdad biológica como el fundamento de la filiación, en el «moderno Derecho de familia» aludido en el voto particular, se extraería la consecuencia inevitable de que los alimentos a los hijos deben pagarlos los verdaderos progenitores; en consecuencia, la mujer que ha sido infiel y ha tenido un hijo que no es del marido debería haber afrontado ella sola el pago de los alimentos al nacido y, al no hacerlo, ha cobrado indebidamente las cantidades abonadas por quien no es el padre biológico. Las dos tesis enfrentadas dialécticamente en la STS de 24 de abril de 2015, que se defienden en ella con mucha más argumentación que la aquí expuesta, tienen robustos puntos de apoyo, pero en mi opinión es más razonable la sustentada por la mayoría de los magistrados, porque a la postre la realidad biológica no puede ser suficiente asidero para decidir sobre una cuestión con tantas aristas como la obligación de alimentos debidos por los padres a los hijos ${ }^{4}$.

En este trabajo me voy a centrar en tres casos que se han planteado recientemente ante la Sala Primera del Tribunal Supremo, casos con los que queda perfectamente ejemplificado el problema que pretendo abordar sobre la dificultad de encontrar un justo equilibrio entre la búsqueda de la verdad biológica y la estabilidad del estado civil de filiación, esto es, entre el interés legítimo del hijo o del padre/madre (biológico o putativo) en que la filiación legal coincida con la biológica, y el interés legítimo del hijo o del padre y/o la madre en que la filiación legal ya determinada (coincida o no con la biológica) permanezca (interés que coincide con el interés general en la seguridad jurídica). Se trata del caso del padre que, sabiendo que lo es desde el nacimiento de dos hijas, reclama su paternidad cuando las hijas ya son mayores de edad y sin que antes se haya ocupado de ellas; del caso de la hija que reclama su verdadera maternidad años después de conocer a la madre biológica, impugnando a la vez la maternidad legal que desde el nacimiento se había determinado, y cuando ambas mujeres ya habían muerto; del caso de quien pide la revisión de una sentencia firme sobre filiación alegando

${ }^{4}$ Defiende también la solución de la sentencia PÉrez CONESA, C., «Impugnación de filiación matrimonial y reclamación de pensión de alimentos (STS de 24 de abril de 2015. Voto particular)», en Revista Doctrinal Aranzadi Civil-Mercantil n. ${ }^{\circ}$ 6/2015. 
como motivo el descubrimiento posterior de la verdad biológica. ¿Puede considerarse contraria a la buena fe, abusiva, la reclamación de la paternidad en los dos primeros casos, por el padre o por el hijo? ¿Cabe entender que verdaderamente tiene interés legítimo en estos casos el padre o el hijo biológicos? ¿Tiene remedios el ordenamiento jurídico para no admitir estas demandas, si es que se consideran efectivamente contrarias a los principios éticos que deben regir nuestra sociedad? ¿Está justificado que un remedio extraordinario como el recurso de revisión, contrario por definición a la estabilidad del estado civil, pueda ser utilizado con fundamento en el descubrimiento de la verdadera filiación biológica?

Creo que los dos intereses mencionados, tanto el que justifica la búsqueda de la verdad biológica como el que defiende la estabilidad del estado civil, entroncan con el derecho a la dignidad de la persona y el libre desarrollo de la personalidad, reconocidos por el artículo 10 de nuestra Constitución, y el derecho a la vida privada y familiar que salvaguarda el artículo 8 del Convenio de Roma de Derechos Humanos. Estos principios básicos de nuestro orden social, la dignidad de la persona y el libre desarrollo de la personalidad (art. $10 \mathrm{CE}$ ), aparecen en las resoluciones adoptadas para resolver los casos enunciados, pero se trata de derechos que valen tanto para el hijo (biológico o putativo) como para el padre (putativo o biológico) ${ }^{5}$. La dignidad y el libre desarrollo de la personalidad del progenitor que quiere hacer coincidir la filiación legal con la real merecen el mismo amparo que la dignidad y el libre desarrollo de la personalidad de quien tiene ya una identidad y un estado civil determinados que quiere seguir manteniendo. En algún caso no puede ofrecer dudas que quedaría vulnerado flagrantemente el interés del hijo menor si se estima la demanda del progenitor

${ }^{5}$ Ha sido puesto de manifiesto que el libre desarrollo de la personalidad «no opera en un ámbito específico, ni ampara una conducta determinada - como lo pudiera hacer, por ejemplo, la libertad de expresión - ya que establece una protección genérica, por lo cual se aplica en principio a toda conducta, lo que lo dota de gran fuerza expansiva y por otro lado, el artículo 10.1 CE prevé una posibilidad muy amplia y general de restricción, en cuanto que la ley (entendida como ordenamiento jurídico), y los derechos de los demás constituyen limitaciones al mismo». (MARTíNEZ VÁzQUEZ DE CASTRO, L., El principio de libre desarrollo de la personalidad en el ámbito priva$d o$, Cívitas Thomson Reuters, 2010, p. 17). También se ha señalado que la dignidad de la persona, en cuanto cláusula principial, se caracteriza «sobre todo por su necesidad de completamiento o integración con otras» (Solozábal, J.J., «Dignidad de la persona», Temas básicos de Derecho Constitucional, tomo III, dir. M. Aragón, Cívitas Thomson Reuters, 2011, p. 113). 
(cuando el que puede ser padre biológico es un delincuente indeseable que ha abandonado a la madre y al hijo y años después reaparece con no se sabe qué aviesas intenciones) $)^{6}$. Tan digna de protección puede ser la vida privada y familiar de quien demanda que su filiación coincida con la realidad como la vida privada y familiar de quien pretende seguir disfrutando de las que ya tiene. Habrá que decidir, por tanto, en cada caso, y atendiendo a las circunstancias concurrentes, qué interés, de los dos enfrentados, resulta más razonable privilegiar y cuál sacrificar. En esta tarea suele tener gran importancia la protección del interés superior del menor, pero no siempre hay menores implicados (como veremos en los casos analizados) y, cuando los hay, su interés puede estar en que su filiación legal coincida con la biológica o, por el contrario, en que su filiación legal se mantenga. Por lo tanto, el interés del menor puede apuntalar tanto el interés legítimo de quien busca la verdad biológica como el interés legítimo de quien quiere seguir disfrutando de un estable estado civil.

En resumen, la dignidad y el libre desarrollo de la personalidad pueden amparar tanto a quien reclama que se determine la filiación verdadera como a quien se opone a ello en defensa de un status quo personal y familiar, pues ambos tienen derecho a que se respete su proyecto vital, que claramente es incompatible con el del otro. La formación de una familia puede considerarse un elemento del libre desarrollo de la personalidad, pero también lo es mantener la ya formada. La dignidad de la persona, como ha sido recalcado por el Tribunal Constitucional, es un valor espiritual y moral inherente a todas las personas que se manifiesta singularmente en la autodeterminación consciente y responsable de la propia vida, constituyendo el punto de arranque para la existencia y especificación de los derechos fundamentales ${ }^{7}$. La doctrina lo considera

${ }^{6}$ Recomiendo la lectura de la SAP Navarra, Sección 2. ${ }^{a}$, n. ${ }^{\circ}$ 15/2015, de 31 de marzo (AC 2015, 575), que se enfrenta a un caso evidente en que el actor puede ser el padre biológico pero no es deseable en absoluto que legalmente conste como tal. Según su propia declaración, el actor (nacional guineano con antecedentes penales por delitos de lesiones y tráfico de drogas) abandona a la madre española antes del nacimiento del hijo y 7 años después reclama su paternidad; la madre alega que solo mantuvieron una relación de amistad y se opone a la práctica de pruebas biológicas. Se desestima la demanda por falta de legitimación activa, lo que permite la ley $71 \mathrm{del}$ Fuero Nuevo de Navarra (el extenso razonamiento de la sentencia se apoya en gran medida en las tesis de la profesora BARBER CÁRCAMO, R., «Nuevos retos ante el Derecho español de filiación», en Revista de Derecho Privado, julio-agosto 2009, pp. 3 y ss., entre otras aportaciones).

${ }^{7}$ El resumen es de Martínez VÁzQuez de CASTRo, L., El principio de libre desarrollo de la personalidad en el ámbito privado, ob. cit., p. 18. 
como un concepto jurídico indeterminado prácticamente de imposible aprehensión ${ }^{8}$. Y aunque se ha utilizado dicho concepto como fundamento de nuevos derechos fundamentales, como la libertad informáti$\mathrm{ca}^{9}$, no parece que la dignidad de la persona pueda servir para justificar el mejor derecho de quien reclama que se determine la filiación biológica frente a quien defiende mantener como familia la que no se sustenta en la filiación biológica.

Creo también que ha de distinguirse entre la verdad biológica como principio inspirador del sistema de filiación y la verdad biológica como elemento de identidad persona ${ }^{10}{ }^{10}$. La necesidad de distinguir entre reglas de determinación del estado civil e instrumentos de conocimiento de la verdad biológica, dos temas que suelen confundirse erróneamente, dotaría de claridad al ordenamiento. Una cosa es el derecho a conocer los propios orígenes, la proveniencia genética, que es expresión del derecho a la identidad personal, y sobre todo se ha planteado en supuestos de adopción y no se traduce en el derecho a tener estado de hijo. Y otra cosa es el derecho a la identidad filial, que es el derecho a la determinación del estado de hijo. Con base en esta distinción puede buscarse el equilibrio necesario entre certeza y estabilidad del estado civil y conocimiento de los propios orígenes.

\section{EL CASO DEL PADRE QUE QUIERE SERLO CUANDO EL HIJO ES MAYOR DE EDAD}

\section{La solución dada por la STS de 3 de diciembre de 2014}

Hay padres que no quieren serlo hasta bastante tiempo después de nacido el hijo. ¿Debe proteger el ordenamiento el interés del progenitor biológico que no ha querido ser padre cuando el hijo lo necesitaba? Así lo entendió la STS de 3 de diciembre de $2014^{11}$, que resuelve sobre una demanda de reclamación de paternidad sin posesión de estado que pre-

${ }^{8}$ Vid. citas de sentencias y autores en Gutiérrez Gutiérrez, I., Dignidad de la persona y derechos fundamentales, Marcial Pons, 2005, pp. 91 y ss.

${ }_{9}$ Vid., sobre esta fuerza generadora de derechos de la dignidad, la investigación de GutiérRez GutiÉRrez, I., Dignidad de la persona y derechos fundamentales, ob. cit., pp. 103-104.

${ }_{10}$ Lo pone también de manifiesto BIANCA, M., «Il diritto del minore ad avere due soli genitori: riflessioni a margine della decisione del Tribunale di Roma sull'erroneo scambio degli embrioni», ob. cit., p. 203, a la que sigo en las siguientes afirmaciones.

11 RJA 2014, 6258. Ponente: Excmo. Sr. Eduardo Baena Ruiz. 
cisa la impugnación de la paternidad determinada legalmente (arts. 133 y 134 CC). Sin embargo, con posterioridad el legislador ha reformado el artículo 133 CC precisamente para evitar que se den casos como el resuelto por la STS de 3 de diciembre de 2014, al que se le podría haber dado otra solución incluso antes de la reforma legal (como se defiende en el voto particular formulado a esta sentencia).

El demandante es un hombre casado, conocidamente infiel, en el momento de la concepción y nacimiento de las hijas demandadas, y que como ginecólogo asiste a la madre durante sus embarazos y partos, consciente de ser el padre de las nacidas. Pero no las reconoce, ni les asiste económica ni afectivamente. Quien las reconoce, en 1996, es otro hombre que conocía a la madre desde 1981, antes del nacimiento por tanto; este es el padre legal también demandado, quien se ha encargado de la educación y sostenimiento económico de las niñas a las que dio su apellido. Y que se opone a la demanda interpuesta por quien, teniendo ya las hijas más de 18 años, invoca su derecho como progenitor biológico a que se determine la paternidad verdadera.

En este caso, la demanda de reclamación de paternidad no matrimonial, y consecuente impugnación de la paternidad no matrimonial determinada, dirigida contra las hijas (ya mayores de edad pues habían nacido en 1986 y 1991, respetivamente), su madre y el varón que había reconocido a las niñas en 1996 y ejercido como padre hasta entonces, fue desestimada por el Juzgado de Primera Instancia e Instrucción de Ubrique (sentencia de 1 de septiembre de 2010) pero estimada al apelarse la anterior sentencia (SAP Cádiz, Sección 5. a, de 29 de mayo de 2013): falla la Audiencia que el demandante es el padre biológico de Marta y María (llamémoslas así) y en consecuencia no lo es el demandado, y que el primer apellido de Marta y María será en adelante el primero del demandante; todo lo cual debe hacerse constar en el Registro Civil. La convicción de la Audiencia sobre la veracidad de la paternidad reclamada se sustenta en la negativa de los demandados a que se practiquen pruebas biológicas unida a otros indicios - amplia prueba documental y testifical- (art. 767.4 LEC).

Los recurrentes en casación esgrimen varios argumentos para combatir la estimación de la demanda, que en esencia pueden resumirse así: la prescripción de la acción de reclamación (motivo primero del recurso), el ejercicio contrario a la buena fe y con abuso de derecho de la acción de reclamación y consecuente impugnación de la paternidad contradictoria (motivo segundo del recurso), la falta de legitimación del progenitor para ejercer la acción de filiación interpuesta (motivos terce- 
ro y cuarto del recurso), y la justificación de la negativa a someterse a la práctica de pruebas biológicas (motivo quinto del recurso).

Defienden los recurrentes que en un caso en que el demandante conocía el nacimiento desde que se produjo, y también su paternidad, la acción para reclamar dicha paternidad prescribe a los 15 años, en aplicación del artículo 1964 CC (el art. 133 CC, cuando se aplica al progenitor sin posesión de estado, debe ponerse en relación con el principio de seguridad jurídica proclamado en el art. 9.3 CE).

Los recurrentes consideran un flagrante abuso de derecho, prohibido por el artículo $7 \mathrm{CC}$, el ejercicio extemporáneo e intempestivo de la acción de filiación entablada, que colisiona gravemente con el prevalente interés de las hijas en preservar su propia identidad y los vínculos familiares, afectivos y sociales hasta entonces establecidos, y con el derecho a la intimidad personal y familiar de las hijas. En opinión de los recurrentes, la demanda supone un grave atentado a la posesión de estado familiar que durante muchos años han mantenido los cuatro demandados, cuando el actor ni ha convivido con las hijas ni las ha mantenido económicamente, ni educado, ni se ha preocupado por sus estudios ni su salud, ni las ha cuidado ni protegido, ni les ha procurado una formación.

Los recurrentes intentan convencer a la Sala de que su doctrina sobre la legitimación del progenitor sin posesión de estado para reclamar la paternidad «no puede ampararse indiscriminadamente en generalizaciones que puedan dañar seriamente pacíficas situaciones personales constantes surgidas de la generosidad de quienes asumen los deberes inherentes a la paternidad en bien del menor y del menor mismo, por lo que hay que ponderar otros intereses que puedan justificar la restricción de la legitimación», y que debe fijarse como doctrina que carece de legitimación activa (ad causam y ad processum) quien reclama su paternidad, impugnando la contradictoria, intempestivamente porque conoce que es el padre del nacido desde el nacimiento. Invocan la doctrina sentada por las SSTS de 28 de mayo de 1997 y 1 de febrero de 2002. El fundamento constitucional de esta limitación de la legitimación para accionar se sustenta en la prevalencia que ha de darse a derechos fundamentales del hijo demandado (arts. 9.3, 10, 18.1, 39.1, 3 y 4 CE), frente a los que puede invocar el demandante en apoyo de su pretensión (art. 39.2 CE). Pretenden los recurrentes que se fije como doctrina «la de que el derecho a la intimidad personal y familiar y a la propia imagen y la seguridad jurídica en el ámbito de las relaciones familiares prevalece sobre el derecho a la investigación de la paternidad del último in- 
ciso del artículo 39.2 de la CE - que cede frente a los anteriores derechos - en supuestos como el de autos».

Por último, los mismos derechos fundamentales que excluyen la legitimación del progenitor no matrimonial para reclamar la paternidad en el caso de autos pueden invocarse, a juicio de los recurrentes, para justificar su negativa a someterse a la práctica de pruebas biológicas.

Algunos de estos argumentos son poderosos, aun partiendo de la premisa insoslayable de que es inconstitucional el artículo $133 \mathrm{CC}$ por no conceder legitimación al progenitor no matrimonial sin posesión de estado para reclamar que se declare la filiación, por vulnerar su derecho a la tutela judicial efectiva en relación con el principio constitucional de libre investigación de la paternidad. El Tribunal Supremo, sin desconocer esta doctrina constitucional, podría haber distinguido supuestos y establecido limitaciones a la legitimación de los progenitores no matrimoniales sin posesión de estado (así lo hace el magistrado Arroyo Fiestas en su voto particular); sin embargo se ha enrocado en que estas limitaciones solo puede establecerlas el legislador, y así ha sido declarado por el máximo intérprete de la Constitución ${ }^{12}$.

La STS de 3 de diciembre de 2014 tuvo la ocasión perfecta para hacer uso de conceptos generales del Derecho en una situación clara de falta de ley (debido a la declaración de inconstitucionalidad del art. 133 en su redacción originaria), y así delimitar la legitimación que debe re-

${ }^{12}$ Por citar solo otro caso reciente en que debe elegirse entre filiación biológica y estabilidad familiar, en el proceso que conduce al ATS de 15 de abril de 2015 (RJA 2015,1343 ) también los demandados intentan que no se estime la demanda interpuesta por el varón que reclama la paternidad no matrimonial de un menor que tiene ya 7 años, y que tiene establecida una filiación matrimonial. Aunque ya están divorciados los demandados, y la madre incluso ha convivido después con el actor y tenido otro hijo, ambos defienden que se mantenga la paternidad del marido. La negativa de los demandados a la práctica de pruebas biológicas, que unida a la existencia de unos mensajes de teléfono lleva a estimar la demanda interpuesta, hace pensar que el amante de la esposa es muy probablemente el padre biológico, y esta realidad es la que prevalece frente al muy probable interés del menor en que siga teniendo como padre legal a quien ha ejercido como tal desde su nacimiento (es llamativo que la madre, tras convivir con el actor y tenido otro hijo con él, se oponga a la demanda, y que el defensor judicial nombrado al menor ni se persone ante el Tribunal Supremo, lo que hace dudar de la utilidad de esta figura en todos los procesos de filiación). En este caso el padre matrimonial alega que la negativa está justificada en la presunción de paternidad y la posesión de estado, sin que la demanda tienda a la protección del menor pues este ya está protegido, y la madre invoca el abuso del derecho a la investigación de la paternidad que comete el actor, y el perjuicio del menor que resulta de la demanda interpuesta cuando este ya tiene 7 años, pero el Tribunal Supremo inadmite los recursos interpuestos pues no hay vulneración de su doctrina jurisprudencial. 
conocerse al progenitor para reclamar la paternidad no matrimonial sin posesión de estado de modo que se garantice su derecho a la tutela judicial efectiva pero no se vulneren derechos que merecen una protección preferente. Pero por distintos motivos (unos formales y otros de fondo), no admitió ninguno. Por el contrario, el Tribunal Supremo, con base en la inactividad del legislador, declara que «la situación actual en España es de legitimación abierta al progenitor sin plazo, con independencia de existencia o no de posesión de estado». Y se mantiene inamovible en esta jurisprudencia. Expresamente razona en la sentencia de 3 de diciembre de 2014, para excluir la existencia de interés casacional en el primer motivo del recurso (infracción de los arts. 1964 y $133 \mathrm{CC}$, en relación con el art. 9.3 CE) pues no procede modificar la jurisprudencia anterior, que «en tanto en cuanto el legislador no dé respuesta a la exigencia que en ellas se recoge, la legitimación del progenitor sin posesión de estado para reclamar la paternidad no matrimonial se encuentra equiparada a la del hijo, conforme a la interpretación que se hace del artículo 133.1 del Código Civil y, por tanto, sin sujeción a plazo. Téngase en cuenta, además, que el plazo puede ser una limitación para el ejercicio de la acción, pero el legislador puede optar por otras, como ya hemos expuesto, siendo por tanto este y no la Sala la que debe dar cumplimiento a la exigencia del Tribunal Constitucional como con toda claridad se expresa este». Y para desestimar el motivo tercero (infracción de la jurisprudencia que declara la necesidad de ponderar otros intereses que puedan justificar la restricción de la legitimación), se razona que conforme a la doctrina constitucional «el progenitor tiene legitimación sin plazo para ejercitar la acción de reclamación de paternidad no matrimonial sin posesión de estado», y aun haciéndose eco de los peligros que para la seguridad jurídica y la paz familiar puede suponer tal legitimación sin límites, «la elección y concreción de tales limitaciones corresponde al legislador, y al día de hoy no se han fijado». El motivo cuarto (infracción de los artículos 18.1, 9.2, 10 y 39.1, 3 y 4 CE) se desestima por las mismas razones, añadiendo que «resulta difícil encajar en la infracción de preceptos de la Constitución la legitimación del progenitor en los términos planteada, cuando es el intérprete de ella el que se la ha otorgado en su Sentencia de Pleno 273/2005, de 27 de octubre, y en la 52/2006, de 16 de febrero». En cuanto al motivo quinto (infracción de los mismos artículos constitucionales, respecto de la práctica de pruebas biológicas), también se desestima «porque a partir de la STC 7/1994, de 17 de enero, existe el deber de soportar estas pruebas siempre que sean consideradas indispensables por la autoridad judicial y no entrañen un grave quebranto para la salud». Admitida la legi- 
timación del actor, cae por su peso la alegación de que estaría justificada la negativa por la falta de legitimación del demandante.

El motivo segundo, relativo a la infracción del artículo 7 CC, se desestima sin entrar en el fondo de la cuestión, ya que considera el Tribunal Supremo que ni en primera instancia ni en apelación se hace pronunciamiento alguno sobre si la acción de reclamación de paternidad ejercitada se adecúa o no al principio general del Derecho sobre la buena fe en el ejercicio de los derechos o si incurre o no en abuso de derecho.

\section{Cómo podría haberse resuelto por el Tribunal Supremo:} falta de interés legítimo del progenitor biológico y abuso de derecho

Algunos autores han considerado razonable y adecuada la posición del Tribunal Supremo reconociendo legitimación activa durante toda su vida al progenitor no matrimonial sin posesión de estado, a falta de previsión legal, argumentando que es la solución del Código Civil cuando se concede legitimación a los protagonistas de la relación de filiación ${ }^{13}$. Discrepo de este razonamiento, pues esa legitimación se concede cuando existe posesión de estado constante, lo que justifica que no prescriba la acción para conseguir que la filiación vivida coincida con la legal, y no es equiparable el interés del padre/madre a que quede determinada su paternidad/maternidad, con el interés del hijo. A pesar de lo establecido por el artículo $132 \mathrm{CC}$, no me parece justificado que a falta de posesión de estado pueda el progenitor, matrimonial o no matrimonial, reclamar durante toda su vida la filiación ${ }^{14}$.

En mi opinión, de las SSTC 273/2005, de 27 de octubre, y 52/2006, de 16 de febrero, no cabe deducir que en cualquier caso un progenitor no matrimonial está legitimado para que se declare su paternidad biológica $^{15}$. El Tribunal Constitucional dicta su doctrina en relación con un

13 Verdera Server, R., «Artículos 127-133», en Comentarios al Código Civil, tomo I, dir. R. Bercovitz, Tirant lo Blanch, 2013, p. 1366.

${ }^{14}$ Comparto la opinión de FerRer RIBA, J., «Paternidad genética y paz familiar: los límites a la impugnación y a la reclamación de la paternidad», en Revista Jurídica de Catalunya, 2006-3, pp. 122-123, sobre la discriminación que supone distinguir la legitimación para accionar en función de si la filiación es matrimonial o no matrimonial, faltando la posesión de estado.

${ }_{15}$ Para una exposición detallada de la doctrina constitucional, me remito a QUICios Molina, M.S., Determinación e impugnación de la filiación, Thomson Reuters Aranzadi, 2014, pp. 98 y ss, Las consecuencias indeseadas de una extensión generalizada de la solución reflejada han sido señaladas, por ejemplo, por LlEDó YAGÜE, F., 
determinado caso, y así lo señala: en la ponderación de los intereses en presencia «en relación con el supuesto que ha dado origen a la presente cuestión», el legislador ha ignorado por completo el eventual interés del progenitor en la declaración de la paternidad no matrimonial. El propio Tribunal Constitucional insiste en que las limitaciones a la legitimación del progenitor sin posesión de estado están justificadas para impedir la utilización abusiva de la acción de reclamación de la filiación, y en particular la imposición de límites temporales a la posibilidad de ejercicio de la acción. Aunque un límite temporal rígido solo puede establecerlo el legislador (y a él dirige su doctrina el Tribunal Constitucional, pues solo el legislador puede regular con carácter general la legitimación de los progenitores para reclamar la filiación), creo que los tribunales de justicia, y en particular el Tribunal Supremo, pueden utilizar otros medios para interpretar y aplicar el Derecho del modo que mejor garantice los intereses en conflicto. $\mathrm{Y}$ esto no lo ha excluido el Tribunal Constitucional.

¿En qué casos puede estar justificada la legitimación activa del progenitor no matrimonial para que se declare la paternidad biológica? Cuando ha sido diligente y, sin culpa suya, no ha podido determinarse la paternidad. Es entonces cuando se cercena de raíz el derecho a obtener la tutela judicial efectiva de su interés a que se investigue la paternidad, cuando, en la ponderación de valores constitucionales involucrados, se anula por completo uno de ellos (el del progenitor no mencionado en el art. $133 \mathrm{CC}$ ). Es en estos supuestos en los que la eliminación del acceso a la jurisdicción no guarda la necesaria proporcionalidad con la finalidad perseguida de proteger el interés del hijo y de salvaguardar la seguridad jurídica en el estado civil de las personas. El artículo $133 \mathrm{CC}$ es inconstitucional porque no permite, en ningún caso, la reclamación de la paternidad por el progenitor biológico, lo que no significa que siempre deba concederse la legitimación al progenitor biológico. Los tribunales pueden utilizar conceptos generales para limitar la legitimación del progenitor si se entiende que no tiene interés legítimo para reclamar la filiación o resulta injustificado el sa-

«Tema 19. Las acciones de filiación», en Los 25 temas más frecuentes en la vida práctica del Derecho de Familia, tomo I, Lledó Yagüe y Sánchez Sánchez (dirs.), Dykinson, 2011, p. 545, pensando precisamente en un supuesto como el enjuiciado por la STS de 3 de diciembre de 2014: pueden dañarse seriamente pacíficas situaciones personales constantes surgidas de la generosidad de quienes asumen los deberes inherentes a la paternidad en bien del menor (STS de 1 de febrero de 2002). 
crificio de los intereses del demandado pues el actor abusa de su derecho a que se determine la paternidad biológica ${ }^{16}$.

Creo que acierta en su voto particular el magistrado Arroyo Fiestas. Entiende que el actor carece de legitimación activa en el proceso, por lo que debe entenderse infringido el artículo 133 CC. En su opinión, serían estimables los motivos tercero, cuarto y quinto del recurso porque, en el caso, el actor no tiene interés legítimo para accionar. Y ese interés legítimo es necesario acreditarlo para reclamar la paternidad, comparando los artículos 131 y $133 \mathrm{CC}$.

La falta de interés legítimo deriva del comportamiento del actor, que conociendo su paternidad biológica hace dejación de sus obligaciones como progenitor, permite que las hijas consideren padre biológico a quien las reconoce como tal, y muchos años después pretende modificar el estatus jurídico-familiar de las hijas, alterando sus apellidos, que son la forma de ser conocidas en sociedad. Dicho cambio de apellidos provoca una grave afectación de su derecho a la intimidad, como manifestación del necesario respeto a su dignidad como personas. Se altera, pues, la seguridad jurídica a la que razonablemente podían aspirar las hijas, y se produce «una intolerable y odiosa perturbación de su marco familiar de referencia». En síntesis, se vulnerarían los derechos o principios reconocidos por los artículos 9.3, 10, 18.1 y 39 CE. Por el contrario, los demandados sí estarían legitimados para oponerse al reconocimiento de una filiación que no ha estado acompañada del ejercicio de las obligaciones que ello conllevaba, sin causa alguna que lo justificase: «Junto a la manifiesta pasividad del demandante en lo relativo a sus obligaciones paternofiliales nos encontramos con la constitución de un legítimo y efectivo núcleo familiar alternativo, con proyección registral y pública, que pretende desmantelarse con afectación de derechos fundamentales de las demandadas sin causa legítima que lo justifique». El magistrado discrepante considera que de la doctrina constitucional contenida en las SSTC 273/2005 y 52/2006 «se extrae apoyo interpretativo de los preceptos mencionados en el sentido de que hay que velar por la seguridad jurídica, proscripción de

16 Decía De la Cámara, M., en Comentarios al Código Civil y Compilaciones Forales, dir. M. Albaladejo, tomo III, vol. 1, Edersa, 1984, p. 611, que la exigencia de posesión de estado para que el progenitor pueda reclamar su paternidad «elimina prácticamente el riesgo de que un progenitor egoísta que se ha desentendido de los deberes que su paternidad o maternidad le imponen, trate de reclamarla con el único propósito de beneficiarse. La posesión de estado presupone, lógicamente, que, de hecho, el progenitor ha cumplido las obligaciones que le incumben, salvo supuestos casi inimaginables en que siempre cabría negarle la legitimación activa». 
pretensiones abusivas, dignidad de la persona, protección de la seguridad familiar y otorgando prevalencia al hijo».

Si no hay interés legítimo del actor, aunque la filiación reclamada responda a la biológica, no quedará determinada por falta de legitimación activa, lo que se decidirá al resolver sobre el fondo.

En fin, debe tenerse en cuenta que en la STS, de 17 de febrero de $2015^{17}$, siguiendo la estela de la STC 167/2013, de 7 de octubre, se ha resuelto que el hijo menor de edad demandado puede conservar como primer apellido el de la madre aunque se determine la paternidad reclamada por quien ejerce tardíamente la acción de reclamación: en contra de una interpretación literal del artículo 109 CC, se invoca el interés superior del menor y el derecho al nombre, como signo de identidad protegido por el derecho fundamental a la propia imagen (art. $18 \mathrm{CE}$ ). Como ha sido resaltado por la doctrina ${ }^{18}$, este pronunciamiento no es una sanción al ejercicio tardío, pues ya lo sostuvo la STC 167/2013 sin distinguir supuestos (lo relevante es el paso del tiempo desde el nacimiento hasta la determinación de la filiación).

\section{Cómo podrá resolverse tras la reforma del artículo 133 CC}

El legislador español ha reformado en el año 2015 normas esenciales atinentes a la determinación extrajudicial de la filiación y a las acciones de filiación. Por lo que respecta a las modificaciones del régimen de determinación extrajudicial de la filiación, se contienen en la Ley 15/2015, de 2 de julio, de la Jurisdicción Voluntaria (BOE de 3 de julio), y en la Ley 19/2015, de 13 de julio, de medidas de reforma administrativa en el ámbito de la Administración de Justicia y del Registro Civil (BOE de 14 de julio) ${ }^{19}$. De particular importancia son las disposi-

${ }^{17}$ STS n. $^{\text { 76/2015, de }} 17$ de febrero (RJA 2015, 924). Ponente: Excmo. Sr. D. Eduardo Baena Ruiz.

${ }^{18}$ Díaz Martínez, A., «Buena fe, retraso desleal y actos propios en el ejercicio de acciones de filiación», en Revista Doctrinal Aranzadi Civil-Mercantil, n. ${ }^{\circ}$ 4/2015, p. 4.

${ }_{19}$ El artículo 2 de la Ley 19/2015 ha dado nueva redacción a varios artículos de la Ley 20/2011, de 21 de julio, del Registro Civil; la disposición final segunda de la Ley 19/2015 ha modificado el artículo 120 del Código Civil; la disposición final quinta, de la Ley 19/2015, ha modificado la Ley 14/2006, de 26 de mayo, sobre técnicas de reproducción humana asistida (concretamente, los artículos 7.3, 8.2 y 9.3). La reforma del artículo $120 \mathrm{CC}$ y de la LTRHA ha sido motivada por la reforma de la LRC/2011. Todos estos artículos reformados entran en vigor el 15 de octubre de 2015 (disposición final décima de la Ley 19/2015, y disposición final décima LRC/2011, disposición que 
ciones relativas a la determinación de la filiación materna y paterna contenidas en el nuevo artículo 44, y concordantes, de la Ley del Registro Civil de 2011, artículo que entrará en vigor el 15 de octubre de $2015^{20}$. Las modificaciones relativas a las acciones de filiación se han

también ha sido modificada por la Ley 19/2015 — art. 2.10 - , para retrasar la entrada en vigor de la LRC/2011 al 30 de junio de 2017 con la salvedad indicada - la reforma de la LRC/2011 contenida en el art. 2 de la Ley 19/2015 entra en vigor el 15 de octubre de 2015-). La redacción de la disposición final décima de la LRC/2011, insistimos con esta salvedad, es la vigente, pues la redacción que le dio la disposición final cuarta de la LJV, apartado 12, a la disposición final décima de la LRC/2011, sin dicha salvedad, quedó derogada al entrar en vigor inmediatamente después la Ley 19/2015.

${ }^{20}$ La determinación extrajudicial de la paternidad y de la maternidad, a partir del 15 de octubre de 2015, sufre cambios, motivados por el deseo del legislador de conseguir que la inscripción de los recién nacidos se realice directamente desde los centros sanitarios, a través de «ventanilla única», donde los padres, asistidos por los facultativos que hubieran asistido al parto, firmarán el formulario oficial de declaración al que se incorporará el parte facultativo acreditativo del nacimiento, que se remitirá telemáticamente desde el centro sanitario al Registro Civil (Preámbulo de la Ley 19/2015, apartado IV). La finalidad última perseguida es posibilitar la tramitación electrónica desde los centros sanitarios de los nacimientos, como medida necesaria para ejecutar una propuesta del Informe realizado por la Comisión para la Reforma de las Administraciones Públicas creada por el Consejo de Ministros de 26 de octubre de 2012 (Preámbulo de la Ley 19/2015). Así que se reforman artículos claves del Código Civil y de la Ley de Técnicas de Reproducción Humana Asistida, sobre el Derecho sustantivo de filiación, para conseguir una mayor eficiencia de la Administración. Esa «ventanilla única» a la que se refiere el legislador se trata de conseguir obligando a promover la inscripción de nacimiento, con carácter preferente, a la dirección de hospitales, clínicas y establecimientos sanitarios, y al personal médico o sanitario que haya atendido el parto, cuando este haya tenido lugar fuera de establecimiento sanitario (art. 45.1 y 2 LRC/2011, modificado por la Ley 19/2015). En estos casos, dispone el artículo 46 LRC/2011, también modificado por la Ley 19/2015, que la comunicación del nacimiento se realizará mediante la remisión electrónica del formulario oficial de declaración debidamente cumplimentado por el centro sanitario y firmado por la persona o personas que tengan la obligación de comunicar el nacimiento (los progenitores, según el art. 45.3 LRC/2011), formulario que comprenderá la identificación y nacionalidad de los declarantes, y sus declaraciones relativas al nombre elegido para el recién nacido, el orden de sus apellidos y su filiación paterna. Esta declaración sobre la filiación paterna, en el formulario oficial del nacimiento que debe comunicarse en un plazo de setenta y dos horas a la Oficina del Registro Civil que corresponda, es la que debe insertarse en el sistema de filiación ya establecido. Si el nacimiento se hubiera producido fuera de establecimiento sanitario, o habiéndose producido en un centro sanitario este no hubiera remitido el documento al que está obligado, los obligados a promover la inscripción (progenitores, pariente más próximo o, en su defecto, cualquier persona mayor de edad presente en el lugar del alumbramiento al tiempo de producirse) dispondrán de un plazo de diez días para declarar el nacimiento ante la Oficina del Registro Civil o las Oficinas Consulares del Registro Civil (art. 47.1 LRC/2011, modificado por 
introducido en la Ley 26/2015, de 28 de julio, de modificación del sistema de protección a la infancia y a la adolescencia (BOE de 29 de julio). El artículo 2 modifica, entre otros, el artículo $133 \mathrm{CC}$, y la modificación ha entrado en vigor a los veinte días de su publicación en el BOE (18 de agosto de 2015). A partir de esta fecha, los progenitores no matrimoniales pueden ejercitar la acción de reclamación de su paternidad o maternidad en el plazo de un año contado desde que hubieran tenido conocimiento de los hechos en que hayan de basar su reclamación.

En la Ley 26/2015 el legislador se ha limitado a responder a la exigencia de reforma de los artículos 133 y 136 CC que el Tribunal Constitucional le había reclamado, dada su declaración de inconstitucionalidad; no ha abordado una reforma del régimen de las acciones de filiación que solucione otros problemas prácticos a los que los tribunales deben enfrentarse (por ejemplo, si está o no legitimado el reconocedor para impugnar la filiación reconocida a sabiendas de no ser el verdadero progenitor). Diez años después de las SSTC 138/2005, 16/2005, 273/2005 y 52/2006, se legaliza la legitimación del progenitor no matrimonial para reclamar su paternidad o maternidad, aun no existiendo posesión de estado, y la legitimación del marido para impugnar su paternidad legal en el momento en que tenga conocimiento de que no es el padre biológico. La reforma es muy importante porque prácticamente todas las demandas de reclamación de la filiación se sustentan en el artículo $133 \mathrm{CC}$, dada la inexistencia de posesión de estado, y muchas de las demandas de impugnación de la paternidad (no accesorias de la reclamación de otra contradictoria) las interpone el marido de la madre - se impugna la filiación matrimonial- .

El artículo 133 CC se compone, tras su modificación, de dos números, referido el primero a la legitimación del hijo y el segundo a la legitimación del progenitor. En el número 1 se ha mantenido la redacción originaria del artículo 133 con una ligera variación en el segundo párrafo, referente a la legitimación de los herederos del hijo: la tendrán, en lugar de «si el hijo falleciere antes de transcurrir cuatro años desde que alcanzare plena capacidad», «si el hijo falleciere antes de transcurrir cuatro años desde que alcanzare mayoría de edad o recobrare capacidad

la Ley 19/2015). Como la declaración de nacimiento dentro de este plazo de diez días se efectuará presentando el documento oficial debidamente cumplimentado acompañado del certificado médico preceptivo firmado electrónicamente por el facultativo o, en su defecto, del documento acreditativo en los términos que reglamentariamente se determinen (art. 47.2 LRC/2011), constará la maternidad y, en su caso, la declaración de filiación paterna. Para inscribir la declaración de nacimiento fuera del plazo previsto de diez días se precisará resolución dictada en expediente registral (art. 47.3 LRC/2011). 
suficiente a tales efectos» (no varía la legitimación de los herederos del hijo si este fallece en el año siguiente al descubrimiento de las pruebas en que se funde la demanda). En cuanto a la legitimación del progenitor, la regla por la que ha optado el legislador en el número 2 del artículo 133 es que «podrán ejercitar la presente acción de filiación los progenitores en el plazo de un año contado desde que hubieran tenido conocimiento de los hechos en que hayan de basar su reclamación». Los herederos del progenitor solo podrán continuar la acción que su causante hubiera iniciado en vida: se declara expresamente que la acción del progenitor no es transmisible a los herederos (la misma regla cabe deducirla del art. $132 \mathrm{CC}$, cuando la filiación que se reclama es la matrimonial y no existe posesión de estado); por tanto, no se les reconoce legitimación proprio nomine, lo que me parece una buena decisión pues la falta de posesión de estado aconseja limitar el grupo de personas legitimadas activamente, para así garantizar el principio de seguridad jurídica (art. 9.3 CE).

La legitimación del progenitor aun sin posesión de estado ha sido, pues, legalizada, limitándose temporalmente. Se ha establecido el límite que como ejemplo daba la STC 273/2005, de 27 de octubre, al declarar inconstitucional el artículo $133 \mathrm{CC}^{21}$. Debe analizarse si el plazo de caducidad establecido por el legislador, con el dies a quo fijado, atiende adecuadamente los diversos intereses enfrentados: el interés del progenitor en ver determinada su paternidad biológica, el interés del hijo en mantener la identidad y las relaciones familiares disfrutadas hasta entonces y el interés del padre o la madre legales en mantener la familia creada. En definitiva, debe encontrarse el justo equilibrio entre el respeto a la libre investigación de la paternidad (art. 39.2 CE) que exige una tutela judicial efectiva (art. $24 \mathrm{CE}$ ) y el respeto a la seguridad jurídica (art. 9.3 CE) y estabilidad familiar (art. 39.1 CE) ${ }^{22}$.

${ }^{21}$ Otras posibles restricciones para combatir el ejercicio abusivo o contrario a la buena fe de la acción fueron sugeridas por GARCía VICENTE, J.R., «La previsible reforma del derecho de las acciones de filiación. Algunas propuestas», en Derecho Privado y Constitución, . $^{\circ} 20$, enero/diciembre 2006, pp. 227 y ss.).

${ }^{22}$ El Tribunal Europeo de Derechos Humanos ha considerado en varias de sus sentencias que limitaciones establecidas por las legislaciones nacionales a la investigación de la paternidad no vulneran el derecho a la vida privada reconocido por el artículo 8 del Convenio, limitaciones que tienden a conseguir precisamente el equilibrio adecuado entre los intereses contrapuestos del progenitor a ver declarada su paternidad y del hijo que vive en paz una situación familiar (vid. BARBER CÁRCAMO, R., «La jurisprudencia del Tribunal Europeo de Derechos Humanos sobre acciones de filiación: análisis y prospectiva», en Derecho Privado y Constitución, n. ${ }^{\circ}$ 20, enero/diciembre 
Está claro que el caso resuelto por la STS de 3 de diciembre de 2014 (y tantos otros, como el de la también mencionada STS de 17 de febrero de 2015, que resuelve sobre el orden de los apellidos) tendría un final distinto si le hubiera sido aplicable el nuevo artículo 133.2 CC. Habiendo quedado probado que el actor sabía que era el padre biológico de las hijas demandadas desde su nacimiento, habría pasado con creces el plazo de caducidad establecido por el legislador cuando interpone la demanda (recordemos que las hijas ya eran mayores de edad). Por tanto, el legislador soluciona satisfactoriamente los casos en que se pruebe que el conocimiento de los hechos en que base su reclamación el actor ha tenido lugar más de un año antes de la interposición de la demanda.

¿Qué podemos entender por «desde que hubieran tenido conocimiento de los hechos en que hayan de basar su reclamación», que es la expresión utilizada por el legislador para fijar el dies a quo del plazo de caducidad establecido? En el Anteproyecto de la Ley de Protección a la Infancia de 2014 se fijaba un dies a quo distinto: el año contaba desde que los progenitores tuvieran conocimiento de las pruebas en que hayan de basar su reclamación. En otro lugar defendí que el conocimiento de esas pruebas, por lo que a la paternidad concierne, debía interpretarse como conocimiento del nacimiento del hijo en un momento en que, por el tiempo transcurrido desde las relaciones sexuales mantenidas con la madre, resulta posible la paternidad reclamada, pues la prueba de la filiación es en puridad el objeto del juicio ${ }^{23}$. Esta interpretación puede mantenerse con la redacción, más apropiada, del artículo 133.2 CC. Por lo que respecta a la maternidad, la cuestión es más compleja, pues si ha de reclamarse judicialmente es porque, en contra de lo que es habitual, no quedó determinada al nacer el hijo ${ }^{24}$.

2006, pp. 145 y ss.). Cita algunas de estas resoluciones la STS de 3 de febrero de 2014, que reconoció los peligros para la seguridad jurídica y la paz familiar de una legitimación sin límites del progenitor sin posesión de estado.

${ }^{23}$ Quicios Molina, M.S, Determinación e impugnación de la filiación, Thomson Reuters Aranzadi, 2014, pp. 111-112.

${ }^{24}$ A tenor del artículo 44.4, párrafo 2. ${ }^{\circ}$ LRC/2011, modificado por la Ley 19/2015, vigente desde el 15 de octubre de 2015 , la filiación materna de la mujer que da a luz, ya esté o no casada, se hará constar necesariamente en toda inscripción de nacimiento ocurrida en España, salvo en los casos de menores abandonados desconociéndose su filiación: el artículo 48 LRC/2011 dispone para estos casos de menores desamparados que las entidades públicas de las Comunidades Autónomas competentes en materia de protección de menores deberán promover sin demora su inscripción, así como la inscripción de la tutela administrativa que, en su caso, asuman, sin perjuicio de la anotación de la guarda que deban asumir. En el Preámbulo de la Ley 19/2015, que no modifica el artículo 48 LRC/2011, se enfatiza que «en el ámbito de la protección de la infancia, se establece la no 
Pensemos precisamente en los hechos que enjuicia la STS de 12 de enero de 2015 (y que veremos en el siguiente apartado), e imaginemos que es la madre la que quiere que se determine su maternidad biológica años después de haber dado a luz a la niña que entrega al matrimonio que la inscribe como hija natural suya. ¿Cuándo podríamos entender que esta madre tiene conocimiento de los hechos en que basa su reclamación? El hecho esencial en que basa su reclamación es su maternidad biológica, conocida obviamente desde que se produce el parto, respecto de una niña que voluntariamente entrega en una adopción irregular. Si la madre biológica desconociera la identidad de los padres legales, y solo años después descubriera que la hija que tuvo es la que consta como hija de este matrimonio, habría que entender que tiene un año desde entonces para reclamar su maternidad. Porque el hecho del nacimiento, desconociendo la identidad de la hija nacida, no basta para dar comienzo al plazo de caducidad de la acción.

obligatoriedad de la madre que renuncia a su hijo en el momento del parto a promover la inscripción de nacimiento, pasando esa obligación a la Entidad Pública correspondiente, sin que, en tal caso, el domicilio materno conste a los efectos estadísticos, evitando el consiguiente efecto de empadronamiento automático del menor en el domicilio de la madre que ha renunciado a su hijo». Efectivamente, el artículo 45.3 LRC/2011 (modificado por la Ley 19/2015, y por lo tanto en vigor desde el 15 de octubre de 2015) establece que, aunque los progenitores están obligados a promover la inscripción de nacimiento, en caso de renuncia al hijo en el momento del parto, la madre no tendrá esta obligación, que será asumida por la Entidad Pública correspondiente. ¿Cuándo entra en vigor el artículo 48 LRC/2011, al que se remiten los artículos 44.4 y 44.5 LRC/2011? Entiendo que el 15 de octubre de 2015, porque ningún sentido tendrían estos artículos sin el artículo 48 LRC/2011. Si la madre renuncia a ejercer los derechos derivados de la filiación materna, el acceso a la inscripción de nacimiento y filiación será restringido (art. 44.4, párrafo segundo, LRC/2011). También estará sujeto al régimen de publicidad restringida, y no figurará a efectos estadísticos, el domicilio de la madre si hubiera renunciado a su hijo en el momento del parto (art. 49.4 LRC/2011, modificado por la Ley 19/2015). Para que no se produzcan casos de cambios de bebés, el médico, el enfermero especialista en enfermería obstétrico-ginecológica o el enfermero que asista al nacimiento, dentro o fuera del establecimiento sanitario, comprobará, por cualquiera de los medios admitidos en derecho, la identidad de la madre del recién nacido a los efectos de su inclusión en el parte facultativo (art. 44.3 LRC/2011); en caso de discordancia entre la declaración del nombre de la madre y el parte facultativo o comprobación reglamentaria, prevalecerá este último (art. 44.4, párrafo segundo in fine LRC/2011). Se declara en el Preámbulo de la Ley 19/2015 que en cuanto a la seguridad en la identidad de los nacidos se ha atendido la alarma social causada por el drama de los «niños robados», incidiendo la ley en la seguridad de identificación de los recién nacidos y la determinación, sin género de dudas, de la relación entre la madre y el hijo, a través de la realización, en su caso, de las pruebas médicas, biométricas y analíticas necesarias; por otra parte, se multiplican los controles para el caso de fallecimiento de los nacidos en los centros sanitarios tras los primeros seis meses de gestación. 
Un último comentario sobre el artículo 133.2 CC, de Derecho transitorio. El Tribunal Supremo ha entendido que antes de la reforma legal del artículo 133 no podía limitarse temporalmente la legitimación del progenitor no matrimonial sin posesión de estado, ni siquiera en casos en que es discutible que el actor tenga interés legítimo y puede entenderse que incurre en abuso de derecho, mientras que a partir de la entrada en vigor de la reforma deberán desestimarse las demandas interpuestas fuera del plazo de caducidad establecido por el legislador. ¿Cómo deben resolverse los procesos judiciales ya iniciados, pero en los que todavía no ha recaído sentencia firme? Si calificamos la norma contenida en el artículo 133.2 como sustantiva, no procesal, no es indiscutible que pueda aplicarse a los procesos ya iniciados. Pero la normal irretroactividad de las leyes, en este caso, no es seguro que proceda, porque tras la declaración de inconstitucionalidad del artículo 133 ha sido la jurisprudencia la que le ha dado un contenido más extenso que el reconocido por el legislador en 2015: la situación es de alegalidad. Dado que la jurisprudencia puede variar con la suficiente justificación, lo razonable será resolver los procesos ya iniciados con arreglo a la norma contenida en el reformado artículo 133, pues no estaría en absoluto justificada una doctrina jurisprudencial como la contenida en la STS de 3 de diciembre de $2014^{25}$.

${ }^{25}$ En el Derecho navarro, que contiene una regla similar a la del artículo 133 CC en la ley 71 del Fuero Nuevo, no se plantearía esta problemática situación, porque a pesar de los intentos hechos para que el Tribunal Constitucional decida sobre la constitucionalidad del precepto navarro, no ha recaído sentencia que lo declare inconstitucional. Y de momento sigue sin llegar al Tribunal Constitucional una cuestión de inconstitucionalidad que denuncie la vulneración de los derechos que fueron tomados en consideración para declarar inconstitucional el artículo 133 CC. No ha estimado procedente presentarla la SAP Navarra, Sección 2. ${ }^{a}$, n $^{\circ}$ 15/2015, de 31 de marzo (AC 2015, 575). El caso real resuelto, que puede ocurrir en cualquier lugar, debería llevarnos a extremar la prudencia en cuanto a la admisión y estimación de demandas de reclamación de paternidad amparadas en la libre investigación de la paternidad biológica, pues algunas pueden conllevar especiales trastornos a la vida privada y familiar del hijo. Un varón guineano reclama su paternidad respecto de un menor español de 7 años de edad, nacido en 2004. La madre reconoce haber tenido amistad con el actor, persona con antecedentes penales por delitos de lesiones y tráfico de drogas, cuyo paradero es desconocido durante varios periodos de la vida del menor; su versión es que mantuvo relaciones sexuales con la madre en la época de la concepción y después la abandonó. Se admite a trámite la demanda (el principio de prueba invocado por el actor es que es de raza negra y el hijo demandado mulato) pero no se ordena la práctica de prueba biológica, negándole al actor legitimación activa para reclamar su paternidad no matrimonial sin posesión de estado. Una solución, en mi opinión, absolutamente justa. 


\section{EL CASO DEL HIJO QUE QUIERE SERLO CUANDO EL PADRE O LA MADRE HA FALLECIDO}

\section{La solución dada por la STS de 12 de enero de 2015}

Hay hijos que no quieren serlo hasta mucho tiempo después de conocer quién es su padre o su madre biológicos. Incluso esperando a la muerte del que siempre ha constado como tal y del que biológicamente lo es. ¿Debe proteger el ordenamiento el interés del hijo en que quede determinada legalmente su paternidad o maternidad biológicas? Así lo ha entendido la STS de 12 de enero de $2015^{26}$.

En 1968 da a luz en la Clínica Santo Celo, de Valencia, una, imaginamos, señorita de buena familia que había ingresado un tiempo antes con un nombre supuesto. La recién nacida (llamémosla Belén) es inscrita en el Registro Civil de Barcelona como nacida en dicha ciudad e hija biológica del matrimonio formado por don Donato y doña Noelia. No es una niña robada del tristemente conocido Santo Celo de Valencia; hubo consentimiento de la madre biológica para que la niña tuviera como padres al matrimonio barcelonés, que en lugar de adoptarla la inscribieron como hija por naturaleza. En febrero de 1992 Belén tiene noticias de que sus padres legales no lo son biológicos, y que su verdadera madre es doña Gracia, quien en ese momento se encontraba casada con don Rogelio y tenía cuatro hijas matrimoniales. En mayo de 1992 Belén y doña Gracia se conocen, y un año después Belén también conoce a su verdadero padre (de cuya identidad había sido informada por doña Gracia). En septiembre de 1993 se someten a pruebas biológicas, que dan un resultado positivo. Don Donato falleció el 28 de agosto de 2002, y doña Noelia el 14 de mayo de 2007; en 2009, Belén aceptó

${ }^{26}$ RJA 2015, 610. Ponente: Excmo. Sr. Eduardo Baena Ruiz. En otras ocasiones ya habían resuelto los tribunales de instancia sobre supuestos semejantes de reclamaciones tardías que son calificadas por los demandados de abusivas. En el caso resuelto por la SAP Murcia de 14 de octubre de 2010, el demandante espera a que fallezca el marido de su madre, que desde los 30 años sabe no es su verdadero padre, para reclamar la paternidad del hombre que había tenido una aventura con su madre e impugnar, consecuentemente, la paternidad matrimonial. Un caso similar encontramos en la SAP Córdoba, Sección 2. ${ }^{\mathrm{a}}$, de 3 de diciembre de 2010 (TOL 2.259.754), en el que la hija reclama la paternidad no matrimonial después del fallecimiento del padre biológico. La SAP Sevilla de 13 de febrero de 2007 no admite la existencia de abuso de derecho ni mala fe procesal en el ejercicio tardío de la acción de reclamación por la hija, dado su naturaleza imprescriptible y tratarse de derechos irrenunciables e indisponibles por ser materia de orden e interés público. 
expresamente la herencia de estos en escritura pública en concepto de hija. Don Rogelio falleció el 25 de febrero de 2010, y doña Gracia falleció el 5 de abril de 2010. Poco después de esta última fecha, Belén ejercita acción de reclamación de filiación materna no matrimonial con impugnación de la filiación contradictoria y acción de declaración de heredera de doña Gracia, considerándose preterida en el testamento otorgado por su verdadera madre el 16 de febrero de 2010.

El Juzgado de Primera Instancia n. ${ }^{\circ} 5$ de San Sebastián, en sentencia de 31 de octubre de 2011, estimó la demanda de filiación (la actora había desistido de sus pretensiones sucesorias, una vez advertida por el Juzgado la indebida acumulación de acciones planteadas). No entiende el Juzgado que haya ejercicio abusivo de la acción, ni retraso desleal ni contradicción con los actos propios. Las hijas matrimoniales de la madre fallecida recurrieron en apelación, y la SAP San Sebastián, Sección 2 . $^{\mathrm{a}}$, de 3 de mayo de $2013^{27}$ lo estimó revocando la sentencia de primera instancia: se admite que hay retraso desleal y contradicción con actos propios (aceptación como hija de la herencia de sus padres registrales, que la habían instituido heredera).

La actora recurre en casación, y los motivos segundo y tercero del recurso son estimados por el Tribunal Supremo (el primer motivo, desestimado, no interesa para el análisis crítico de la sentencia). En el motivo segundo alegaba la recurrente que la sentencia se oponía a la doctrina jurisprudencial relativa al retraso desleal en aplicación del artículo 7.1 CC en los supuestos de reclamación de filiación por parte del hijo (art. 133 CC), en relación con los artículos 10 y 39 CE (SSTS de 16 de mayo de 2000, 11 y 12 de abril de 2012). En el motivo tercero alegaba la recurrente que la sentencia se oponía a la doctrina jurisprudencial relativa a los actos propios en aplicación del artículo 7.1 CC (SSTS de 26 de mayo de 2009, 15 de enero de 2013 y 18 de junio de 2010).

El Tribunal Supremo expone su doctrina sobre el fundamento constitucional de la imprescriptibilidad de las acciones de filiación, contenida en las SSTS de 11 y 12 de abril de 2012, y su consideración de tal imprescriptibilidad como razón para entender que el retraso en el ejercicio de la acción de reclamación desde que el actor conoce su origen biológico no constituye, en principio, abuso de derecho; como no puede calificarse de ilícita una motivación económica para conseguir el éxito de una acción de reclamación (aunque no se admitiría el fraude de ley, para lo que habría que determinar la norma defraudada y el resultado contrario que produci-

27 TOL 4.371.961. 
ría en el ordenamiento jurídico español) ${ }^{28}$. En esencia, la acción para reclamar la determinación de la filiación biológica es una manifestación del principio de protección de la persona, que es preferente en nuestro ordenamiento por declaración expresa del artículo $10 \mathrm{CE}$; de ahí que se garantice la libre investigación de la paternidad por el artículo 39.2 CE, que abre la puerta a las obligaciones impuestas en el artículo 39.3 CE. Dice el Tribunal Supremo que declarando imprescriptible la acción de reclamación se protegen determinados principios e intereses generales que son superiores a otros presentes y absolutamente legítimos, pero que no tienen la preponderancia de aquellos especialmente protegidos: si desarrollamos esta idea, resulta que la protección de la dignidad del hijo, que tiene derecho durante toda su vida a que se establezca su verdadera filiación, debe prevalecer sobre la seguridad jurídica que demandaría el mantenimiento de una situación consentida por todos los protagonistas.

Comparada esta doctrina con la de la sentencia recurrida, resulta que efectivamente se infringe aquella. Recalca el Tribunal Supremo que son las concretas circunstancias que rodean el ejercicio de la acción las que hacen inferir a la Audiencia el carácter abusivo de la misma, por desleal: la actora, con su conducta, genera falsas expectativas de aceptación del status quo tanto a sus padres registrales como a la progenitora biológica, y busca heredar, fraudulentamente, a dos madres por naturaleza. Pero según el Tribunal Supremo no pueden tomarse en consideración los hipotéticos derechos sucesorios de la demandante, pues solo se está ejercitando una acción de reclamación de filiación

${ }^{28}$ La magistrada ponente de ambas sentencias de 2012 es la Excma. Sra. Dña. Encarna Roca Trías. En la STS n. ${ }^{\circ}$ 208, de 11 de abril de 2012 (RJA 2012, 5745), una mujer de 38 años reclama la paternidad no matrimonial, impugnando la matrimonial contradictoria, cuando el padre biológico ya ha fallecido, al igual que el padre legal. En esta historia, la madre había mantenido una relación sentimental con el padre biológico durante 50 años (de 1958 a 2008), pero se había casado en 1968 con otro hombre (el padre matrimonial de la demandante, fallecido en 1992). La demanda se dirige contra los herederos del padre biológico, que entre otras líneas de defensa invocan el ejercicio extemporáneo del derecho y contrario a los actos propios de la demandante - la hija había conocido quién era su verdadero padre a los 11 años y había dejado pasar 20 , desde que alcanzó la mayoría de edad, para reclamar su verdadera filiación - . En la STS n. ${ }^{\circ}$ 209/2012, de 12 de abril de 2012 (RJA 2012, 5898), se reclama la paternidad no matrimonial por la hija, que no parece haber tenido ningún contacto con el padre, después del fallecimiento del progenitor en 1996, siendo demandados la viuda y el hijo matrimonial ya mayor de edad. Tanto en primera como en segunda instancia se estima la demanda, y no se aprecia abuso de derecho (la demandada había alegado que se pretendía obtener un inconfesado rendimiento patrimonial treinta años después de una esporádica relación de fin de semana). 
materna no matrimonial, imprescriptible para garantizar la dignidad de la persona (sobre estos derechos sucesorios incompatibles deberá decidirse, en su caso, en juicios futuros relativos a los mismos): «Cercenar por abusiva o desleal una acción en cuya virtud solo se decide algo tan sustancial a la dignidad de la persona como es su filiación por haber utilizado la actora los tiempos con fines sucesorios no es posible, sin perjuicio, como decimos, de que tales retrasos y combinaciones temporales puedan valorarse con arreglo a derecho en futuros litigios con pretensiones de otra naturaleza, si llegasen a plantearse». En ningún caso sirven estas circunstancias para justificar el mantenimiento de un estado civil falsario en cuanto a la filiación (dice el Tribunal Supremo). Y tampoco cabe vincular a la actora con sus actos de aceptación del status quo pues la acción de filiación es indisponible.

\section{Cómo podría haberse resuelto por el Tribunal Supremo: abuso del derecho del hijo biológico}

Fue señalado hace años que «es sumamente inconveniente en el orden práctico que puedan plantearse indefinidamente cuestiones sobre la filiación de las personas. Basta pensar en los perjuicios que puede originar el ejercicio de una acción de reclamación fundada en un interés hereditario mucho tiempo después de la apertura de la sucesión, lo que obligará, si la acción triunfa, a un nuevo replanteamiento de aquella» ${ }^{29}$. En el sistema de filiación de nuestro Código Civil no cabe determinación de la maternidad o de la paternidad como mera declaración de la verdad biológica; siempre se derivarán los efectos de la filiación establecida. Es por ello que, aun considerando que un derecho esencial de cualquier persona es el derecho a conocer el propio origen, y que tal derecho fundamenta la libre investigación de la paternidad (y de la maternidad) ${ }^{30}$, como todo derecho tiene sus límites, y cuando la investigación de la paternidad o la

${ }^{29}$ De la Cámara, M., en Comentarios al Código Civil y Compilaciones Forales, cit., pp. 611-612. Concluía el autor que «esta reflexión induce a apurar el análisis de las hipótesis en que la ley no se pronuncia expresamente, con el fin de encontrar algún punto de apoyo que pudiera ser favorable a la caducidad». Previamente advierte que el principio de la imprescriptibilidad de las acciones de filiación se halla más bien en crisis, pues la posibilidad de remover indefinidamente el estado de filiación de que goza una persona determinada choca contra la seguridad jurídica (ob. cit., pp. 511-512).

${ }^{30}$ Como ya puntualizó en su día SerRano Alonso, E., «La Constitución y las relaciones privadas concretas. La filiación», en Constitución y relaciones privadas, Cuadernos de Derecho Judicial, 2003, p. 163. 
maternidad no se detiene en el puro conocimiento del origen biológico, sino que lo trasciende pues se derivan todos los efectos que como estado civil tiene la filiación, puede que sea necesario calibrar tales efectos al analizar la demanda de investigación de la paternidad o maternidad para decidir sobre el conflicto de intereses planteado. No tienen por qué recibir la misma solución las demandas de personas que solo piden saber quién fue su madre o su padre (no previstas por el legislador común), que las demandas de personas tendentes a que se determine la maternidad o paternidad con plena eficacia personal y patrimonial.

En el Proyecto de Ley de modificación del Código Civil en materia de filiación, patria potestad y régimen económico matrimonial de 14 de septiembre de 1979, origen de la reforma de 1981, se sujetaba la acción de reclamación de la filiación no matrimonial, sin posesión de estado, a un plazo de caducidad. En dicho Proyecto, la acción de reclamación de filiación no matrimonial cuando falta la respectiva posesión de estado podía ejercitarse por el hijo durante su minoría de edad y hasta que transcurriesen diez años después de haber llegado a la plena capacidad, y aunque hubiesen transcurrido diez años, podía también deducir la acción durante el año siguiente al descubrimiento de las pruebas en que se funde la demanda (párrafos I y II del art. 133 en el citado Proyecto) ${ }^{31}$. El Grupo Comunista presentó una enmienda ofreciendo una nueva redacción al artículo 133: «La acción de reclamación de filiación es imprescriptible, pero la caducidad de la acción de impugnación de filiación determinará la de la primera en los casos en que sea precisa la acumulación de ambas»; y el Grupo de Coalición Democrática presentó otra enmienda proponiendo el siguiente tenor: «La acción de reclamación de filiación no matrimonial, cuando falte la respectiva posesión de estado, corresponde al hijo y podrá ejercitarse durante su menor edad y hasta que transcurran cuatro años después de haber llegado a la plena capacidad». En el Dictamen de la Comisión, después de rechazarse en el Informe de la Ponencia las enmiendas presentadas y defender el mantenimiento del texto del Proyecto, aparece la redacción definitivamente aprobada $^{32}$. El legislador de 1981 optó, al final, por no establecer ningún plazo de caducidad para que el hijo pueda ver determinada su filiación $^{33}$. Pero eso no obsta para que el juez aplique conceptos generales

${ }^{31}$ Código Civil (Reformas 1978-1983). Trabajos Parlamentarios, I, Cortes Generales, 1985, § 4, p. 178 .

${ }^{32}$ Código Civil (Reformas 1978-1983), cit., § 4, pp. 256, 271, 388 y 4301.

${ }^{3}$ Según PeÑa Bernaldo de Quirós, M., «Título V. De la paternidad y filiación», en Comentarios a las reformas del Derecho de Familia, vol. I, Tecnos, 1984, p. 980 , 
como el abuso de derecho a situaciones para las que no está justificado mantener la protección al interés invocado al ejercer el derecho a la investigación de la paternidad.

La legitimación activa del hijo para reclamar que se declare judicialmente su filiación biológica durante toda su vida, aunque no haya posesión de estado, no ha sido cuestionada por la doctrina. Se ha señalado que probablemente «va implícito en la dignidad de la persona el derecho a conformar su estado civil sin más limitaciones que aquellas estrictamente exigidas por especiales intereses de terceros y que justifican su caducidad en casos determinados. Fuera de ellos, parece razonable dar preferencia al interés de una persona en regularizar su estado y ajustarlo a la realidad frente al interés de los terceros afectados en no ser sujeto pasivo de reclamaciones extemporáneas» ${ }^{34}$. Pero si el interés del hijo puede considerarse espurio, no estaría justificada esa preferencia, entiendo yo.

Los derechos han de ejercitarse conforme a las exigencias de la buena fe sin incurrir en abuso de derecho, ordena el artículo $7 \mathrm{CC}$. Ello significa, por lo que respecta a la buena fe como límite, que el ejercicio del derecho ha de ser conforme con las convicciones éticas imperantes en el momento y lugar en que se ejerce y, por lo que respecta a la interdicción del abuso del derecho, que el ejercicio del derecho debe ajustarse a la finalidad (económica o social) para la que se le atribuyó a su ti$\operatorname{tular}^{35}$. El retraso desleal o la prohibición de ir contra los propios actos se consideran manifestaciones de un ejercicio que no es conforme con la buena fe. El abuso de derecho es una figura utilizada fundamentalmente en conflictos de intereses de índole patrimonial ${ }^{36}$, pero no me

es la solución preferible (la que prevaleció, frente a la del Proyecto, inspirada en cierto sentido en el Código Civil suizo, según expone en nota 6), pues el hijo debe tener acción, mientras viva, para hacer valer la filiación biológica (solución exigida por el art. $14 \mathrm{CE}$, congruente con el principio internacional de que toda persona nacida fuera del matrimonio tiene derecho a que conste su verdadera filiación). A favor de esta solución se pronuncia también QUESADA GONZÁLEZ, M.C., La determinación judicial de la filiación, Bosch, 2012, pp. 341-342.

34 Cavanillas Múgica, S., «Artículo 1961», en Comentarios al Código Civil, tomo IX, dir. R. Bercovitz, Tirant lo Blanch, 2013, p. 13286.

35 TUR FAúnDEZ, M.N., La prohibición de ir contra los actos propios y el retraso desleal, Aranzadi Thomson Reuters, 2011, p. 15.

${ }^{36}$ Carrasco Perera, A, «Artículo 7», en Comentarios al Código Civil, tomo I, dir. R. Bercovitz, ed. Tirant lo Blanch, 2013, p. 171, resume así los lugares típicos en los que la jurisprudencia aplica el artículo $7 \mathrm{CC}$ : conflictos entre propietarios y comunidades de propietarios, conflictos por la toma de acuerdos entre socios minoritarios y mayoría de la sociedad de capital, conflictos relativos a la aplicación de la técnica del 
parece que haya inconveniente para sujetar el ejercicio de los derechos personales o de índole familiar a este límite genérico. En cambio, más dudas puede suscitar la aplicación del retraso desleal o la prohibición de ir contra los propios actos. Es difícil que puedan triunfar, frente a la reclamación de la filiación, argumentos como los esgrimidos en algunos casos: el paso del tiempo sin interponer la acción crea la apariencia de que no se va reclamar, o la aceptación de la herencia del padre legal como un acto propio contra el que iría la reclamación de la filiación del progenitor biológico una vez fallecido para reclamar la legítima correspondiente.

La prohibición de ir contra los propios actos trata de salvaguardar la confianza generada en un tercero por un determinado acto, confianza en que no se va a contradecir después dicho acto: quien pudiendo actuar de un determinado modo genera la confianza de que va a actuar de otro, no podrá después querer actuar como tenía derecho a hacerlo ${ }^{37}$. Pero tratándose de materias indisponibles para el sujeto, como es el estado civil, no puede aplicarse una doctrina tal. Si una persona no puede quedar vinculado por su declaración expresa en relación con una materia indisponible, tampoco podrá quedar vinculado por sus actos. No puede ampararse la confianza generada cuando no está legitimado para esperar tal confianza un tercero. El primer presupuesto es que «una persona haya observado, dentro de una determinada situación jurídica, una cierta conducta jurídicamente relevante y eficaz: una conducta vinculante ${ }^{38}$, pero ni vincula a su autor una conducta por la que se dispone del estado civil ni sería parte de dicha situación jurídica quien después alega la prohibición de ir contra los propios actos. Es argumento para defender que no podría impugnar, en su caso (si entendemos que fija la relación jurídica de filiación como un reconocimiento de complacencia), pero sí reclamar.

Creo que no puede motivarse la inexistencia de abuso de derecho, en el caso resuelto, en los intereses superiores protegidos por la impres-

«levantamiento del velo» societario, reclamaciones de distribuidores por terminación abusiva de los contratos de distribución, reclamaciones de daños producidos por la paralización de obras consecuencia de la interposición de un interdicto de obra nueva.

${ }^{37}$ Sobre el posible fundamento de la prohibición de ir contra los propios actos como imposibilidad de contradecir una declaración de voluntad, vid. TUR FAÚNDEZ, M.N., La prohibición de ir contra los actos propios y el retraso desleal, ob. cit., pp. 3031. Sobre pronunciamientos del TC sobre la prohibición de ir contra los actos propios fuera del Derecho privado patrimonial, vid. p. 33.

38 TUR FAÚNDEZ, M.N., La prohibición de ir contra los actos propios y el retraso desleal, ob. cit., 2011, p. 35. 
criptibilidad de la acción, es decir, en el fundamento de esta imprescriptibilidad, que expresamente se dice que es la protección de la persona (art. $10 \mathrm{CE}$ ) de la que deriva la libre investigación de la paternidad (art. 39.2 CE) «que va a abrir la puerta a las obligaciones impuestas en el párrafo tercero del propio artículo $39 \mathrm{CE}$ ».

Todos los derechos, prescriban o no, se reconocen porque el interés subyacente merece la protección del ordenamiento frente a otros con los que pudiera entrar en conflicto, interés que deja de merecer esta protección si su ejercicio, dentro del plazo posible (los años establecidos o toda la vida del titular), es abusivo ${ }^{39}$. El interés subyacente en la libre investigación de la paternidad, reconocido constitucionalmente en el seno del artículo 39, es la protección de la persona que es o va a ser miembro de una familia, con los derechos y obligaciones asociados a tal condición. Pero quien reclama que se determine su verdadera filiación, impugnando la contradictoria que lleva disfrutando y aprovechando desde su nacimiento, muchos años después de haber alcanzado la mayoría de edad y de haber conocido su verdadera filiación y cuando ya han fallecido tanto el padre putativo como el biológico, no parece que esté necesitado de la protección dispensada por el artículo 39: ninguna obligación asume (salvo la de prestar alimentos a sus hermanastros, si los hubiera - art. $143 \mathrm{CC}-)^{40}$, mientras que se convierte en titular de unos derechos sucesorios que, si se ejercen (y no parece que vayan a dejar de ejercerse en el caso de la STS de 12 de enero de 2015), alterarán gravemente la seguridad jurídica. Efectivamente, si el padre biológico no dejó testamento, quien es declarado hijo del causante en sentencia judicial se convertirá en heredero abintestato, y si el causante hizo testamento, habrá preterición (¿intencionada o no intencionada? Los efectos son muy distintos - vid. art. $814 \mathrm{CC}-$ ). Que en el juicio de filiación no deban tomarse en consideración estas consecuencias sucesorias a la hora de determinar si la demanda es abusiva o no, como sostiene la STS de 12 de enero de 2015, resulta difícilmente justificable, ya que las reglas sobre sucesión abintestato y sobre legítimas en nuestro

39 Carrasco Perera, A, «Artículo 7», en Comentarios al Código Civil, ob. cit., p. 173, califica de perogrullada sin sentido la afirmación jurisprudencial de que no abusa de su derecho quien se limita a ejercitar las prerrogativas que le concede la norma, pues si fuera cierto nunca habría abuso de derecho: hay que interpretarla en el sentido de que como regla no abusa de su derecho quien lo ejercita y quien invoque artículo 7 debe probar la concurrencia de especiales circunstancias concurrentes que hacen reprochable la conducta objetivamente adecuada a la norma.

${ }^{40}$ El actor, ahora, no sufre demasiado coste en su identidad frente a terceros, pues va a mantener los apellidos si así lo quiere el actor (con apoyo en el art. $111 \mathrm{CC}$ ). 
ordenamiento se sustentan precisamente en la familia como institución protectora, pero ninguna familia ha habido antes de la demanda de filiación porque así lo ha querido el propio hijo.

Que la pretensión de una persona a que conste legalmente su verdadera filiación deba considerarse imprescriptible, no significa que el ejercicio de tal derecho en cualquier momento de la vida de la persona deba ampararse por el ordenamiento jurídico. En mi opinión, que sea imprescriptible la acción significa que no caduca dicha acción, y por tanto se considera preferible el derecho del hijo a que se establezca su filiación a la garantía de la seguridad jurídica y otros derechos fundamentales de los legitimados pasivamente. No cabría, por ello, invocar retraso desleal del derecho ni la doctrina de los actos propios ${ }^{41}$. Pero, cuestión distinta, es que no haya de filtrarse la pretensión teniendo en cuenta otros principios éticos; en particular, el abuso del derecho del hijo a reclamar su verdadera filiación o el fraude de ley, si los hubiera, deben ser límites a la pretensión.

\section{Decisiones del Tribunal Europeo de Derechos Humanos}

Cuando la legitimación del hijo para reclamar su verdadera filiación se somete a plazos de caducidad por algún legislador europeo, se ha invocado ante el Tribunal Europeo de Derechos Humanos la violación del artículo 8 del Convenio Europeo de Derechos Humanos por quien ve desestimada su demanda por ese motivo, de modo que no puede quedar establecida legalmente la que podría ser la filiación biológica. Los casos y las soluciones ofrecidas en estas sentencias son muy ilustrativas, por lo que expondré algunas de las más recientes.

En el caso Konstantinidis contra Grecia (STEDH, Sección 1. a , de 3 de abril de 2014) $)^{42}$, el que se dice hijo de un famoso compositor griego interpone una demanda de reclamación de paternidad contra él cuando tiene ya 22 años, y la legislación griega aplicable establece que el hijo tiene un plazo de un año desde que alcanza la mayoría de edad para reclamar su filiación, plazo que se suspende si el hijo desconoce la realidad biológica (interpreta la jurisprudencia griega que el desconocimiento de los hechos en que puede fundarse la demanda de paternidad es un

${ }^{41}$ Sobre la naturaleza extraordinaria del retraso desleal, y su distinción del abuso de derecho, vid. Cavanillas MúgiCa, S., «Artículo 1961», en Comentarios al Código Civil, tomo IX, dir. R. Bercovitz, Tirant lo Blanch, 2013, pp. 13299-13300.

42 JUR 2014, 101417. 
suceso de fuerza mayor, que según la legislación puede oponerse como causa de suspensión de la acción). En el caso enjuiciado, la madre le informa al hijo sobre quién es su padre poco antes de morir, cuando el hijo tiene 19 años, y este inicia entonces una investigación para comprobar la veracidad de esta información: primero se pone en contacto con el presunto padre, que desmiente tal información, y después con su madrina, amiga íntima de la madre, que se la confirma. Es entonces, pasados dos años desde que conoce el dato de quién puede ser su progenitor, cuando ejercita la demanda de reclamación de paternidad. Los tribunales griegos desestiman dicha demanda, pues el plazo de caducidad comenzó a computar el 31 de agosto de 2001 y la demanda no se interpuso hasta el 19 de diciembre de 2003, y no consideran que la conducta del demandado pueda interpretarse como conducta dolosa tendente a la no presentación de la demanda (otra causa de suspensión del plazo de caducidad). La tesis defendida por el demandante ante el TEDH es que el derecho a la vida privada y familiar ampara que no se pongan límites temporales al derecho a conocer los orígenes. El TEDH en esta sentencia insiste en que los plazos de caducidad que limitan las acciones de reclamación de la filiación son admisibles, si bien han de ser flexibles, y en el caso, entrando en colisión, por una parte, el derecho del actor a conocer su ascendencia (integrante de su derecho a la vida privada y familiar) y, por otra parte, el derecho del demandado a su propia vida privada y familiar y el interés general a la protección de la seguridad jurídica, entiende que el Estado griego consigue un justo equilibrio entre tales intereses. Un magistrado de la Sala, aunque no disiente de la solución ofrecida al caso, formula una serie de dudas muy sensatas: debido a la complejidad de las circunstancias que rodean una filiación no matrimonial, cuando es el hijo quien está interesado en la búsqueda de la verdad biológica, los plazos que se fijen para interponer la demanda han de permitir razonablemente al hijo ejercer su derecho, y un año parece un plazo excesivamente corto, sobre todo si se compara con los 10 años que se conceden al progenitor y con los 5 años que tiene la madre del menor para reclamar la paternidad; la mejor opción del legislador, para garantizar el derecho a la identidad biológica del hijo, sería la imprescriptibilidad de la acción tendente a la mera constatación de esta identidad, sin consecuencias patrimoniales. En definitiva, parece indiscutible que el hijo tiene durante toda su vida un interés moral en conocer su identidad, y ello estaría protegido por el artículo 8 del Convenio Europeo de Derechos Humanos, pero no toda su vida un interés a que el estado civil de filiación se modifique, porque la seguridad jurídica y los derechos de terceros podrían quedar afectados injustificadamente. 
En el caso Backlund contra Finlandia (STEDH de 6 de julio de $2010)^{43}$, el hijo reclama la filiación cuando tiene 65 años. Más de 20 años antes había entrado en vigor una ley que concedía cinco años a los nacidos antes de dicha entrada en vigor para reclamar su verdadera paternidad, pero el hijo no había interpuesto entonces ninguna demanda de paternidad (aunque era un hecho conocido que su padre biológico era el demandado). Los tribunales finlandeses rechazan la demanda con base en esta regla. Se enjuicia, pues, un límite temporal a la legitimación del hijo para reclamar su verdadera filiación de naturaleza transitoria, y se llega a la conclusión de que el establecimiento de límites temporales a las acciones de filiación es compatible con el Convenio, pues responde al interés general en mantener la certeza de las relaciones familiares.

\section{REVISIÓN DE SENTENCIAS FIRMES SOBRE FILIACIÓN ${ }^{44}$}

\section{Las SSTS de 12 de diciembre de 2014 y 11 de octubre de 2007}

El 22 de diciembre de 2005 nace en Valladolid una niña que es inscrita en el Registro Civil con los apellidos de su madre, pues solo la filiación materna queda determinada en ese momento. En octubre de 2007 se determina la filiación paterna de esta niña, por sentencia judicial que estima la acción de reclamación de paternidad interpuesta por quien se cree padre de la menor y, consecuentemente, ordena el cambio de sus apellidos para que el primero sea el primero de los del padre. Las pruebas para estimar la demanda son la negativa de la madre demandada a que se practiquen pruebas biológicas unida a otros indicios de la filiación reclamada (art. 767.4 LEC). Es decir, las mismas pruebas que desde la reforma de las acciones de filiación vienen siendo tomadas en consideración por los tribunales para resolver las demandas judiciales sobre filiación a falta de práctica de la prueba indubitada de la filiación

43 TEDH $2010,81$.

${ }^{44}$ No es objeto de estudio la revisión de una sentencia firme sobre filiación cuando el Tribunal Europeo de Derechos Humanos haya declarado que dicha sentencia ha sido dictada en violación de alguno de los derechos reconocidos en el Convenio Europeo para la Protección de los Derechos y Libertades Fundamentales y sus Protocolos, que a partir del 1 de octubre de 2015 será posible con la entrada en vigor del nuevo artículo 510.2 LEC (según ha sido redactado por la disposición final 4.a , apartado 13, de la LO 7/2015, de 21 de julio, de modificación de la Ley Orgánica del Poder Judicial). 
reclamada o impugnada, esto es, la biológica. La madre de nuestra historia había declarado en el juicio que estaba totalmente segura de que el demandante no era el padre biológico, pero se negó a que se practicase prueba biológica ninguna; esta la obtuvo el actor en septiembre de 2011 (según su declaración) con ocasión de la estancia de la menor en su domicilio: en el informe emitido por el laboratorio al que acudió el padre legal los resultados obtenidos le excluyen como padre biológico. En ese momento interpone demanda de revisión de la sentencia que había declarado su paternidad, allanándose a la pretensión tanto la madre como la defensora judicial que fue nombrada en el proceso de revisión (una tía materna).

La demanda de revisión, que se fundamenta en el artículo 510.1 LEC, fue estimada por la STS de 12 de diciembre de $2014^{45}$. Según la norma procesal, habrá lugar a la revisión de una sentencia firme si, después de pronunciada, se recobrasen u obtuvieren documentos decisivos, de los que no se hubiese podido disponer por fuerza mayor o por obra de la parte en cuyo favor se hubiese dictado. Al rescindirse la sentencia de 2007, la menor volverá a llevar los apellidos de la madre.

Esta sentencia tiene un precedente en la STS de 11 de octubre de $2007^{46}$, que accede a la revisión de una sentencia dictada en un proceso de impugnación de paternidad. En este caso, el padre legal había impugnado en 2001 su paternidad respecto de un menor de edad, y la demanda, a la que se había opuesto la madre, se desestimó. Con posterioridad (en junio de 2005), se realiza una prueba biológica extrajudicial que excluye la paternidad del actor, y tanto él como la madre (ambos habían instado la práctica de esta prueba extrajudicial) piden, con apoyo en el artículo 510.1 LEC, la revisión de la sentencia que había desestimado la demanda de impugnación. Se razona que el documento aportado (prueba biológica sobre ausencia de paternidad del demandante) «merece su consideración en el proceso que dio lugar a la sentencia impugnada», y ha de accederse a la revisión porque «en el pleito resuelto por la sentencia cuya rescisión se pretende, se negó la práctica de dicha prueba, que ahora figura en la presente demanda por acuerdo de las partes de aquel pleito».

Se plantean en ambos casos problemas de legitimación activa para pedir la revisión. En la de 2007 resulta chocante que la madre, que como demandada entendemos ha debido negarse a la práctica de la prueba biológica en el juicio, pida después, junto con el padre que pre-

\footnotetext{
${ }^{45}$ STS n. ${ }^{\circ} 755 / 2014$, de 12 de diciembre (RJA 2014, 6655).

${ }^{46} \mathrm{STS} \mathrm{n}^{\circ}{ }^{\circ} 1102 / / 2007$, de 11 de octubre (RJA 2007, 7306).
} 
viamente había impugnado su paternidad, la revisión de la sentencia con base precisamente en el resultado de dicha prueba biológica. Sobre esta cuestión no hizo ningún comentario el Tribunal Supremo. En la de 2014 resulta discutible que esté legitimado quien ha vencido en el juicio, y sobre esta cuestión sí se pronuncia el Tribunal Supremo, como después veremos.

En el caso enjuiciado por la STS de 12 de diciembre de 2014 parecía evidente que el interés del menor coincidía con que no tuviera como padre al que legalmente constaba, ¿pero cabe generalizar la solución? No me parece razonable.

\section{Hacia la absoluta transparencia de la realidad biológica}

¿Puede revisarse una sentencia firme sobre filiación - ya se haya dictado en un proceso de determinación de paternidad o maternidad o en un proceso de impugnación - cuando con posterioridad se descubre que filiación biológica real es distinta a la que sirve de fundamento a dicha sentencia? Saber a ciencia cierta si un varón es o no es el padre biológico de alguien (o una mujer es la madre genética) resulta en la actualidad sencillo comparando los respectivos genes. Basta con tener material genético de ambas personas, material que puede obtenerse antes del juicio, durante el juicio si ambas partes acceden a someterse a la realización de una prueba biológica acordada por el juez o después del juicio. En un juicio sobre filiación, o fuera de juicio, la realización de una prueba biológica permite alcanzar el conocimiento del fundamento de la filiación por naturaleza.

Como hemos visto, el Tribunal Supremo ha accedido a la revisión de sentencias firmes por las que se determinaba la filiación reclamada o, por el contrario, no estimaban la acción de impugnación interpuesta contra una filiación ya determinada, con apoyo en el artículo 510.1. LEC (es el art. 510.1.1. ${ }^{\circ}$ a partir de la entrada en vigor de su modificación por la LO 7/2015, de 21 de julio) ${ }^{47}$. Se interpreta por el Tribunal Supremo que el conocimiento de la verdad biológica tras un proceso en el que se persigue precisamente ese conocimiento, gracias a la práctica de una prueba biológica que no se ha realizado en el juicio, es motivo de revisión, pues, a juicio del Alto Tribunal, se obtiene un documento de-

${ }^{47}$ Vid. disposición final 4. ${ }^{\text {a }}$, apartado 13, de la LO 7/2015, de 21 de julio, de modificación de la Ley Orgánica del Poder Judicial, que entra en vigor el 1 de octubre de 2015 (disposición final 10 .a). 
cisivo del que no se ha podido disponer por fuerza mayor o por obra de la parte en cuyo favor se hubiese dictado la sentencia. En la STS de 12 de diciembre de 2014 se añade un argumento más para estimar la demanda de revisión: el interés del menor.

Creo que una decisión tan trascendental como la revisión de una sentencia firme sobre filiación, estado civil al que vienen asociados tantos efectos de naturaleza personal y patrimonial, merece una mayor reflexión para no convertir en susceptible de revisión cualquier sentencia sobre filiación, dictada en un proceso en el que no se ha practicado la prueba biológica porque el demandado se ha negado a ello.

Para empezar, ¿la prueba biológica es una prueba documental? El resultado positivo o negativo de la prueba se vierte en un documento, pero su naturaleza en el proceso de filiación es pericial. En las dos sentencias se alude al informe pericial que se aporta como sustento de la pretensión de revisión.

Por otra parte, de mayor enjundia es encajar esta doctrina jurisprudencial que admite la revisión de una sentencia con base en el valor probatorio que tiene la negativa a someterse a una prueba biológica, lo que presupone que no es decisiva la realización de la prueba biológica para la resolución del conflicto: en consecuencia, no debería admitirse la revisión. De admitirse la bondad de esta jurisprudencia, más valdría que el legislador estableciese la obligatoriedad de practicar la prueba biológica en cualquier juicio sobre filiación. El sistema no puede resistir la continua revisión de sentencias judiciales una vez que se obtiene el resultado de una prueba biológica no practicada en el proceso (por más que esté limitada esa revisión a quien hubiera sido parte perjudicada por la sentencia firme impugnada - art. 511 LEC - y no pueda solicitarse después de transcurridos cinco años desde la fecha de la publicación de la sentencia que se pretende impugnar ni pasados tres meses desde que se obtuvieron los documentos decisivos - art. 512.1 y 2 LEC -$)^{48}$. Dada la facilidad existente para salir de dudas, la escasa petición de revisión de sentencias firmes no sabemos si es debido a que la negativa a someterse a la prueba biológica suele coincidir con la pretensión del actor (lo que justificaría que se le diera el valor de quasi ficta confessio) o a que hasta ahora la revisión de las sentencias firmes con base en el motivo esgrimido no se ha estimado una solución factible por los abogados defensores. Habrá que esperar a ver si se produce o no un efecto llamada.

${ }^{48}$ Han inadmitido recursos de revisión de sentencias fundados en el descubrimiento de la verdad biológica, por interponerse fuera de plazo, los AATS, Sala Primera, de 5 de febrero y 4 de marzo de 2015 (TOL 4.753 .921 y 4.789.121). 
Por último, legitimado activamente para solicitar la revisión está solamente quien hubiese sido parte perjudicada por la sentencia firme impugnada (art. 511 LEC). Cabe deducir que parte perjudicada es quien ha perdido el juicio (concretamente por no disponer del documento decisivo para defender su pretensión): el actor si no se hubiera estimado la demanda; el demandado si se hubiera estimado. Sin embargo, cuando de lo que se trata es de revisar una sentencia firme sobre filiación, dictada en un proceso en el que no se ha practicado la prueba biológica que con posterioridad se obtiene, reconocer la legitimación activa a cualquiera de las partes es discutible.

Si ha vencido el actor que reclama su filiación, y después descubre que la verdad es otra, no parece que haya sido parte perjudicada por la sentencia firme impugnada. Interpreta, sin embargo, el Tribunal Supremo que parte perjudicada por la sentencia firme impugnada puede ser quien vio estimada su demanda de reclamación de paternidad, quien creía ser progenitor pero no lo es en realidad, y por ello tiene interés en que la realidad biológica resplandezca. En la STS de 12 de diciembre de 2014 se responde a la posible falta de legitimación activa del actor razonando que «la obtención de este documento, prueba biológica sobre ausencia de paternidad, que de haberse conocido hubiera cambiado el sentido del fallo de la sentencia que determinó la filiación y cuya no obtención durante el procedimiento de filiación se debió exclusivamente a la negativa de la aquí demandada, determina el interés del demandante en revisar una sentencia que, a la vista del informe, evidentemente puede determinar la no concordancia entre la realidad biológica y la expresada en el registro».

Si quien pretende la revisión de la sentencia es la parte demandada vencida en el juicio, y por ello perjudicada, resulta que no debería tener legitimación porque parece contrario a la buena fe negarse en el proceso a la práctica de la prueba biológica y después pretender rescindir la sentencia dictada con base en esa negativa alegando el resultado de una prueba biológica practicada con posterioridad. Repárese en que la revisión puede pedirse si se recobra u obtiene un documento decisivo del que no se hubiera podido disponer por obra de la parte en cuyo favor se hubiera dictado la sentencia, lo que es coherente con que esté legitimado para pedir la revisión el perjudicado por la sentencia, no quien haya obtenido una sentencia a su favor. Sin embargo, en la STS de 11 de octubre de 2007 ni se hace mención a este fallo de legitimación activa de la madre que se había opuesto a la demanda de impugnación y después pide la revisión junto con el padre putativo. 


\section{Decisiones del Tribunal Europeo de Derechos Humanos}

El Tribunal Europeo de Derechos Humanos ha tenido varias ocasiones de pronunciarse sobre la adecuación al Convenio de decisiones judiciales nacionales en las que no se ha accedido a la revisión de sentencias firmes sobre filiación, una vez conocida la verdad biológica. Los demandantes alegan la vulneración del artículo 8, esto es el derecho a la vida privada, que incluye el derecho a conocer la ascendencia biológica. Las circunstancias de los casos han de tenerse muy en cuenta, porque justifican las distintas decisiones adoptadas por el Tribunal Europeo. Es importante resaltar que en estos supuestos, como en todos los que se refieren a la determinación o impugnación de la filiación, el derecho a la vida privada y a la vida familiar puede ser esgrimido tanto por quien pretende una modificación del estado civil de filiación como quien se opone a ella, interesado en el mantenimiento del statu quo.

En el caso de la STEDH, Sección 3. a, de 28 de febrero de 2014 (caso Ostece contra Rumanía ${ }^{49}$, se había determinado en marzo de 1981 la paternidad del varón demandado con fundamento en testimonios sobre la relación con la madre del menor en el momento de la concepción y en una prueba biológica no concluyente (análisis de sangre que no excluían su paternidad). En 2003, el hijo ya mayor de edad accede a la petición del padre putativo para realizar una prueba de paternidad extrajudicial, que da un resultado negativo (la madre también consiente este test). Basándose en este informe pericial, el señor Ostace presentó una demanda de revisión de la sentencia donde se determinaba su paternidad alegando que por causas objetivas no había podido hasta entonces pedir la revisión. La demanda de revisión fue inadmitida por no cumplir los requisitos exigidos por la legislación procesal rumana (debía tratarse de un documento existente en el momento de dictarse sentencia del que no tuvieran conocimiento las partes). El demandante invoca ante el TEDH la vulneración del artículo 8 del Convenio de Roma por resultar imposible la obtención de una sentencia que reconozca el hecho indubitado de no ser el padre biológico de quien consta como su hijo; el Gobierno rumano defiende la decisión judicial que impide la reapertura de un proceso de búsqueda de la verdad biológica alegando la necesaria protección de los intereses del hijo menor y de la familia y la protección de la seguridad jurídica. El TEDH llega a la conclusión, en este caso en que no hay ningún conflicto de intereses particulares pues el hijo está conforme con la revisión, de que se ha vulnerado el artículo 8. Como

49 TEDH 2014, 18. 
siempre, busca el justo equilibrio entre los intereses legítimos enfrentados, que en este caso son el interés del demandante en que prevalezca la verdad biológica y el interés general. Como argumento para justificar una decisión distinta a la adoptada en otros casos en que también se pedía la revisión de una sentencia sobre filiación, arguye que no se trata de obligar al hijo a que se someta a una prueba biológica, pues esta ya se ha obtenido con el consentimiento de aquel, y que en los otros casos no era irrazonable hacer prevalecer el interés del menor y de la familia en la que vive sobre el interés del demandante.

Distinta fue la solución a la que se llegó por la STEDH, Sección 2. ${ }^{a}$, de 6 de diciembre de 2011, en el caso Iyilik contra Turquía ${ }^{50}$. Atendiendo a las circunstancias concurrentes, en un caso en que también se había rechazado la demanda de impugnación de la paternidad matrimonial ejercitada por el marido porque los análisis de sangre realizados en 1968 no excluían la paternidad del actor, el TEDH considera que se consigue un justo equilibrio entre los intereses concurrentes declarando la no revisión por los tribunales nacionales de la sentencia que había desestimado la demanda de impugnación. Este pretende, en julio de 2002, que se reabra el proceso judicial de impugnación de la paternidad dado que el avance de la ciencia desde 1968 permitía determinar con certeza si era o no el padre biológico, invocando una regla procesal turca que permite la reapertura de un proceso cuando la imposibilidad de presentar elementos de prueba durante el proceso inicial depende de una causa de fuerza mayor. Los tribunales nacionales rechazaron esta demanda conforme a una jurisprudencia antigua y reiterada según la cual el estado del progreso científico no podía asimilarse a una causa de fuerza mayor. La razón fundamental para no considerar vulnerado el artículo 8 del Convenio es que no resulta arbitrario ni desproporcionado considerar prevalente el interés del hijo en que se mantenga establecida su paternidad matrimonial, frente al interés del demandante en verificar si era o no el padre biológico; en definitiva, el rechazo a la demanda del recurrente, que equivalía a una negativa a ordenar un análisis de ADN, no rompe el equilibrio justo que debe reinar entre los intereses presentes ${ }^{51}$.

Sin embargo, aunque la revisión lleve aparejada la práctica de una prueba biológica para demostrar la verdad biológica cabe entender que

50 TEDH 2011, 103.

${ }^{51}$ El TEDH enfrenta el interés del hijo menor con el interés del demandante, aunque atendiendo a las fechas que aparecen en la sentencia la hija debe tener 36 años cuando se pretende la reapertura del proceso de impugnación. 
su desestimación puede suponer una vulneración del derecho a la vida privada de quien solicita la revisión. Fijémonos también en las circunstancias del caso Jäggi contra Suiza, que resuelve la STEDH, Sección $3 .^{\text {a }}$, de 13 de julio de $2006^{52}$. El demandante había nacido en 1939 de madre soltera, quien atribuyó la paternidad a un varón que, al alegar la existencia de otras relaciones sexuales de la mujer en el periodo de concepción, no fue declarado padre por los tribunales suizos (tal solución, fundada en la exceptio plurium concubentium, era permitida por la regulación nacional en 1948). En 1999, el hijo solicitó la revisión de la sentencia dictada en 1948, demandando a los parientes del varón con quien la madre había mantenido relaciones sexuales, fallecido en 1976 (se hace notar en la STEDH que la renovación de la concesión de la tumba hasta 2016 había sido abonada por el demandante, a quien su madre le había revelado el nombre de su padre en 1958). Solicita la realización de pruebas de ADN exhumando los restos del que puede ser su padre, solicitud que es denegada por la jurisdicción suiza pues el derecho a conocer la propia ascendencia no es un derecho absoluto que pueda prevalecer sobre el derecho del difunto a la dignidad humana, que se traduce en la protección sus restos frente a atentados contrarios a los usos y costumbres, y el derecho de sus parientes al respeto del difunto y a la intangibilidad de su cuerpo. Se resalta por el tribunal suizo que a la edad del demandante (casi 70 años), ha podido construir su personalidad aun desconociendo quién es su padre, y que en el conflicto de intereses subyacente en el caso no parece proporcionado acceder a la petición de revisión y de práctica de una prueba biológica a una persona fallecida. El TEDH, por el contrario, valorando que ninguna trascendencia registral ni patrimonial podía tener la estimación de la demanda, llega a la conclusión de que las autoridades suizas han vulnerado el derecho a la vida privada del demandante al no conseguir un justo equilibrio entre los intereses concurrentes. Se razona que el interés de una persona en conocer sus orígenes no desaparece con los años, y en concreto el demandante ha demostrado este interés durante toda su vida, mientras que el difunto no puede sufrir una injerencia en su vida privada si se acuerda una prueba de ADN sobre el cadáver. Tampoco los familiares del difunto que se oponen a la exhumación del cadáver tienen un interés preferible al del actor (no alegan motivos religiosos ni filosóficos), y la protección de la seguridad jurídica no podría por sí sola bastar para privar al demandante de su derecho a conocer su ascendencia teniendo en cuenta la excepcionalidad del supuesto (la revisión solo

52 JUR 2006, 210705. 
tendría efectos para el demandante). Dos magistrados de la Sala muestran su disconformidad con esta decisión, por lo que respecta a la vulneración del artículo 8 del Convenio. Consideran que el tribunal suizo ha ponderado razonablemente los intereses contrapuestos, aunque pueda no compartirse su decisión, de modo que no se ve motivo para entender vulnerado, atendidas las circunstancias del caso, el derecho a la vida privada del demandante enfrentado al derecho a reposar en paz (se trata de un asunto donde se ponen en juego sutiles cuestiones en materia de tradición, creencias y valores familiares, para las que la jurisdicción doméstica debe tener una mayor libertad de apreciación). 
